\title{
Siderophore Production by Heterotrophic Bacterial Isolates from the Costa Rica Upwelling Dome
}

\author{
By \\ Whitney B. Krey \\ B.S., Texas A\&M University, 2005 \\ Submitted in partial fulfillment of the requirements of the degree of \\ Master of Science \\ at the \\ MASSACHUSETTS INSTITUTE OF TECHNOLOGY \\ and the \\ WOODS HOLE OCEANOGRAPHIC INSTITUTION
}

June 2008

(C)2008 Whitney B. Krey

All rights reserved.

The author hereby grants to MIT and WHOI permission to reproduce paper and electronic copies of this thesis in whole or in part and to distribute them publicly.

Signature of Author

Joint Program in Oceanography/Applied Ocean Science and Engineering Massachusetts Institute of Technology and Woods Hole Oceanographic Institution June 2008

Certified by

Mak Saito

Thesis Supervisor

Ed DeLong

Thesis Supervisor and Chair, Joint Committee for Biological Oceanography Massachusetts Institute of Technology/Woods Hole Oceanographic Institution 


\section{Abstract:}

An increased understanding of heterotrophic bacterial strategies for acquiring nutrients and trace elements is critical for elucidating their impact on biogeochemical cycling in the ocean. It is estimated that iron is a limiting nutrient for phytoplankton growth in over $30 \%$ of the open ocean, but still little is known about bacterial strategies for iron acquisition. Siderophore (Fe ligand) production by bacteria may play a major role in influencing the bioavailability of iron in the ocean. Despite the importance of siderophores in the environment, only limited information from a select group of bacteria is available. On a cruise through the Costa Rica Dome (CRD) upwelling region in July 2005, a library of 867 isolates from five depth profiles inside and outside of the dome was obtained and screened for siderophore production using the Chrome Azurol-S (CAS) assay. Phylogenetic affiliation of 134 isolates was determined by sequencing the 16s rDNA gene, and determined that gamma proteobacteria such as Alteromonas, Pseudoalteromonas, Halomonas, and Marinobacter dominated the collection, while alpha-proteobacteria such as Roseobacter were also represented. The isolates obtained from stations in the CRD showed greater siderophore-producing capabilities between $55 \mathrm{~m}$ and $100 \mathrm{~m}$ while strains isolated from outside the CRD had shallower peak $(\sim 8-35 \mathrm{~m})$ production. Functional group determination showed that hydroxamate production dominated from $50-150 \mathrm{~m}$, while hydroxamate and catechol production is roughly equal in shallower waters. By characterizing the siderophores produced by these isolates and determining the genetic make-up of the population, these findings further our understanding of how heterotrophic microbes affect biogeochemical processes and the competitive nature of nutrient acquisition.

\section{History and Background:}

\section{Microbes and their role in the environment}

Microbes are ubiquitous and significant regulators of many of earth's fundamental processes. Bacteria are found nearly everywhere on Earth, growing in soil, acidic hot springs, radioactive waste, seawater, and deep in the Earth's crust (Fredrickson et al. 2004). Forty million bacterial cells can be found in a gram of soil, and more than a million bacterial cells can be found in a milliliter of fresh water. Approximately $5 \times 10^{30}$ bacteria can be found on Earth (Whitman et al. 1998). In addition to their notorious role 
of causing disease, bacteria are vital in the recycling of nutrients. Despite their importance, most of these bacteria have not been characterized, and less than half of the phyla of bacteria have species that can be cultured in the laboratory (Whitman et al. 1998).

Advances in genomics capabilities are providing a more refined view of the capabilities and complexity of the previously underestimated oceanic microbial community, particularly with respect to diversity and functionality. The challenge is integrating these discoveries at the systems level to elucidate specific microbial functional roles and overall system resilience. Understanding the role of microbes in structuring healthy and stressed marine ecosystems will provide the mechanistic basis for extrapolative models.

Genome sequencing has confronted scientists with the reality that many functional capabilities and molecular mechanisms remain unknown. Evidence suggests that important discoveries remain. The relatively recent discovery of proteorhodopsin genes in bacteria is an example. This light-driven pigment converts light energy into an electrical gradient across the cell membrane, and is thought to be an additional, but not primary, source of energy (Beja et al. 2001). Previously thought to only exist in Archaea, proteorhodopsin has now been found in divergent marine bacterial taxa in diverse environments. Another example of an important metabolic discovery is that of the oceanwide distribution of anoxygenic phototrophic bacteria (Madigan 2003). Their contribution to oceanic energy and carbon budgets is much larger than previously 
thought. Other biogeochemical budgets, such as nitrogen, must now be reconsidered due to fresh evidence for nitrogen fixation in common oceanic systems. It is possible that these, as well as undiscovered metabolic pathways, contribute to oceanic biogeochemical budgets in ways that change our current estimates.

\section{Biological importance of iron}

These notable discoveries highlight our current knowledge limitations, as well as the importance of a thorough understanding of microbial metabolism and environmental interactions. A key component needed to link the contribution of bacteria to oceanic nutrient cycles and higher trophic levels is knowledge of the uptake strategies for nutrients that limit growth (Martinez et al. 2000). One such nutrient is iron. Along with other necessary nutrients such as carbon, nitrogen, and phosphorous, microbes need to take up iron. On a broad scale, iron's importance is illustrated by its involvement with regulating coastal and open ocean microbial diversity, controlling primary productivity levels in large areas of the open ocean, and controlling phytoplankton populations in upwelling regions (Ryther and Kramer 1961, Kirchman et al. 2000, Barber and Ryther 1969). On the cellular level, iron is involved in important biological processes such as

photosynthesis, nitrogen fixation, methanogenesis, $\mathrm{H}_{2}$ production, the trichloroacetic acid (TCA) cycle, oxygen transport, gene regulation, DNA biosynthesis/repair, and detoxification of free radicals (Andrews et al 2003, Crichton and Ward 1992, 1998). 
Oceanic algae and bacteria have a high rate of division and turnover relative to land plants, creating a high turnover of nutrients. Biologically available iron is almost completely depleted in surface waters due to this high turnover and cellular quota. Surface iron concentrations are approximately one millionth that of the concentration inside of the microbial cells (Morel and Price 2003). While most nutrients are effectively recycled and regenerated in their respective part of the water column, depletion due to export is a problem; abiotic scavenging and sinking particles are constantly depleting the iron pool. Because of these export factors, water column iron concentrations increase slightly with depth due to remineralization by bacteria below the photic zone.

Iron has two stable oxidation states (Fe (II) and Fe (III)) that can be manipulated to catalyze a wide number of biochemical reactions. For these biochemical reactions, iron is used by incorporation into proteins, or in complexes forming part of iron-sulfur clusters or heme groups. Incorporating iron into proteins allows for control of the local redox potential (ranging from -300 to $+700 \mathrm{mV}$ ), geometry and spin state of the iron atoms, such that they can fulfill their necessary biological function (Andrews 2003). While Fe (III) is the most widely available form of iron in the ocean, $\mathrm{Fe}$ (II) is ultimately the form that biology utilizes. While certain transporters and iron reductases can draw Fe (II) into the cell, known siderophores only bind Fe (III). Internal mechanisms then reduce the Fe (III) to Fe (II), allowing it to be used within the cell. 
The versatility of iron makes it biologically useful, but there are downsides to using this element. Although iron is the $4^{\text {th }}$ most abundant element in earth's crust, it is widely unavailable to biological systems in the ocean due to its insolubility in aerobic environments at neutral $\mathrm{pH}$, as well as biological factors such as competitive uptake (Sunda and Huntsman 1995). In all, it is estimated that the growth of $30 \%$ of the primary production in the open ocean is limited by iron (Martin et al. 1994, Coale et al. 1996, Moore et al. 2004). Iron in surface seawater is present in extremely low concentrations [typically from $20 \mathrm{pM}$ to $1 \mathrm{nM}$ ], which limits primary production by phytoplankton in regions characterized by high concentrations of nitrate and other nutrients but lower than expected concentrations of chlorophyll (HNLC, high nitrate low chlorophyll) (Gordon et al 1982, Landing and Bruland 1987, Martin at al. 1989, 1991, Bruland et al. 1994).

HNLC regions include the subarctic Pacific, eastern equatorial Pacific, the Southern Ocean, and upwelling regions (de Baar et al. 1990, Martin and Fitzwater 1990, Coale et al. 1996). Heterotrophic bacteria are also limited by low iron levels in HNLC regions, though the complexity of their iron requirements and uptake strategies are poorly understood. In regions where phytoplankton are clearly iron limited, conflicting reports exist on iron limitation in heterotrophic bacteria, further highlighting our limited understanding of the complex cycling of this essential nutrient (Kirchman et al. 2000).

It is estimated that $>99 \%$ of the dissolved iron in seawater is complexed by organic ligands in the North Sea, Western Mediterranean, North Pacific, Northwest Atlantic, and equatorial Pacific (Gledhill and van den Berg 1994, van den Berg 1995, Rue and Bruland 
1995, Wu and Luther 1995, Rue and Bruland 1997). The structural composition of this organic ligand pool is largely unknown. One major stumbling block in the characterization of the natural organic ligand pool is the large-scale sampling that is required. A milligram or more of ligand may be required for characterization, limiting the resolution of the samples that can be analyzed (Macrellis et al. 2001). While no siderophore structures have been characterized from the field, lab and field experiments show that siderophores are a component of this pool (Haygood et al. 1993, Rue and Bruland 1995, Lewis et al. 1995, Wilhelm et al. 1998, Hudson 1998, Hutchins et al. 1999b). Organic ligands isolated in the California upwelling region have been shown to possess iron-binding functional groups typical of siderophores (Macrellis et al. 2001). Most other thorough siderophore characterization has taken place on marine bacterial isolates in the laboratory, allowing for intense structural and binding constant determination. While it has been shown that many bacteria are capable of producing organic iron ligands, and that such ligands exist in the field, the link between the two is still largely a mystery. We need to know more about the source, characteristics and fate of these ubiquitous Fe-binding compounds.

\section{Iron acquisition strategies}

Heterotrophic bacteria constitute up to half of the total particulate organic carbon in ocean waters, and in some regions, such as the subarctic Pacific, heterotrophic bacteria can even contain higher cellular concentrations of iron than phytoplankton. Heterotrophic bacteria thus compete successfully for iron against phytoplankton and cyanobacteria and 
play a substantial role in the biogeochemical cycling of iron in the ocean. However, little is known about the molecular mechanisms used by marine bacteria to sequester iron.

Heterotrophic bacteria have evolved Fe (III) transport systems that enable them to grow in environments containing extraordinarily low concentrations of iron. When iron is scarce, many of these organisms excrete low-molecular mass (300-1000 Da) Fe-binding chelators, called siderophores, that bind free Fe (III) (Neilands and Nakamura 2001). Siderophore production has also been shown in cyanobacteria (Armstrong and van Baalen 1979, Wilhelm and Trick 1994), algae, fungi and plants (Neilands 1984, Suguira and Nomoto 1984). Some marine heterotrophs produce and/or excrete siderophores during iron stress and acquire siderophore-bound iron to fulfill their iron requirements (Trick and Wilhelm 1995).

Many types of siderophores have been isolated from marine bacterial strains. Hydroxamate and catecholate type siderophores seem to be the most prevalent in the bacterial strains studied, but other functional groups such as alpha-hydroxy acids, carboxylic acids, and 2-hydroxyphenyl oxazoline are also found (Hider 1984). However, many of the structures have not undergone full characterization (Lewis et al. 1995). A handful of complete siderophore structures have been determined, but these were isolated from a very small portion of the ocean's diverse bacterial community - and only represent structures produced under laboratory conditions. This highlights the need to better link bacterial siderophore production with behavior in the field. 
The connection between iron transport and siderophores in marine microbes is less understood in comparison to the terrestrial model organisms. Terrestrial siderophores such as enterobactin and desferrioxamine B are produced by E. coli and Streptomyces (O’Brien and Gibson 1970, Pollack and Neilands 1970, Bickel et al. 1960). The precise molecular mechanisms of Fe-siderophore transport are now being elucidated in E. coli and other laboratory strains (Ferguson et al. 1998; Buchanan et al. 1999; Ratledge and Dover 2000). In these model organisms, the Fe-siderophore complex attaches to its cognate receptor on the outer membrane of the cell and is subsequently internalized (Braun and Killman 1999; Ratledge and Dover 2000). Some bacterial receptors recognize more than one siderophore, not necessarily of the same structural type (e.g., FhuE of $E$. coli) (van der Helm 1998). Many bacteria express receptors for siderophores released by other species or for Fe sources contained in their hosts (Braun et al. 1998; Ratledge and Dover 2000). Such uptake systems provide a high degree of selectivity and regulation and enable microbes to scavenge and solubilize Fe from otherwise inaccessible sources.

Much less is known about iron transport by aquatic bacteria, particularly among the heterotrophic marine species. Short-term uptake experiments show that bacteria take up most of the dissolved iron (Tortell et al. 1996; Maldonado and Price 1999) and contain relatively large amounts of $\mathrm{Fe}$ in their biomass compared to other living organisms (Tortell et al. 1996). The reasons for the success of bacteria in acquiring iron under these conditions are not well understood, but they may have to do with their ability to produce 
siderophores and to transport ferric siderophore complexes. The ability of heterotrophic bacteria to produce siderophores has been well established in the laboratory (Barbeau et al. 2003, Granger and Price 1999, Martinez et al. 2001, 2003), and the presence of siderophore-like iron ligands has been established in seawater. A more thorough understanding of the molecular mechanics behind siderophore production will hopefully lead to the ability to actively detect their production in the field, and thus help elucidate the impact heterotrophic bacteria have on the iron cycle in the ocean.

\section{Study site: The Costa Rica upwelling dome}

The Costa Rica Dome (CRD) is an upwelling region located in the eastern tropical Pacific Ocean close to $8^{\circ} \mathrm{N}, 90^{\circ} \mathrm{W}$. It is a seasonal phenomenon, shifting shape, size, and location as wind stress changes. The thermocline of this area reaches to approximately 10 $\mathrm{m}$, creating a dome-like shape and thus giving the feature its name. The Costa Rica Coastal Current, Eastern Equatorial Current, and North Equatorial Current all converge in this area to create a cyclonic gyre. Upwelling velocities as high as $10^{-4} \mathrm{~cm} / \mathrm{sec}$ have been calculated (Hofmann et al. 1981). Upwelling water appears to originate from between 75 and $200 \mathrm{~m}$. (Broenkow 1965).

Upwelling is a phenomenon that brings cold, nutrient rich water up from depth, typically causing increased primary productivity. Upwelling regions are generally dominated by diatom blooms at the autotrophic level. However, the CRD is unique in that it is dominated by cyanobacteria - specifically Synechococcus. Cell densities of 
Synechococcus are higher in the CRD than any other open ocean environment measured, ranging from $0.5 \times 10^{6}$ to $1.5 \times 10^{6}$ cells $/ \mathrm{ml}$ (Goericke and Welschmeyer 1993, Campbell et al. 1994; DuRand et al. 2001, Saito et al. 2005). These numbers are approximately an order of magnitude larger than typical cyanobacterial concentrations in the open ocean (Saito et al. 2005). The KN182-50 cruise in July 2005 was dedicated to characterizing trace metals and cyanobacterial population dynamics in and outside of the CRD.

The heterotrophic bacteria in this distinctive regime are largely uncharacterized. This thesis work focuses on the phylogeny of heterotrophic bacterial isolates from the CRD and their siderophore-producing capabilities with the goal of gaining greater insight into the contribution of heterotrophs to oceanic iron cycling.

\section{Methods:}

Cruise Sampling: Samples used in this work were obtained aboard the UNOLS ship R/V Knorr, July 15-August 2, 2005 on the KN182-50 cruise. 


\section{Cruise track}

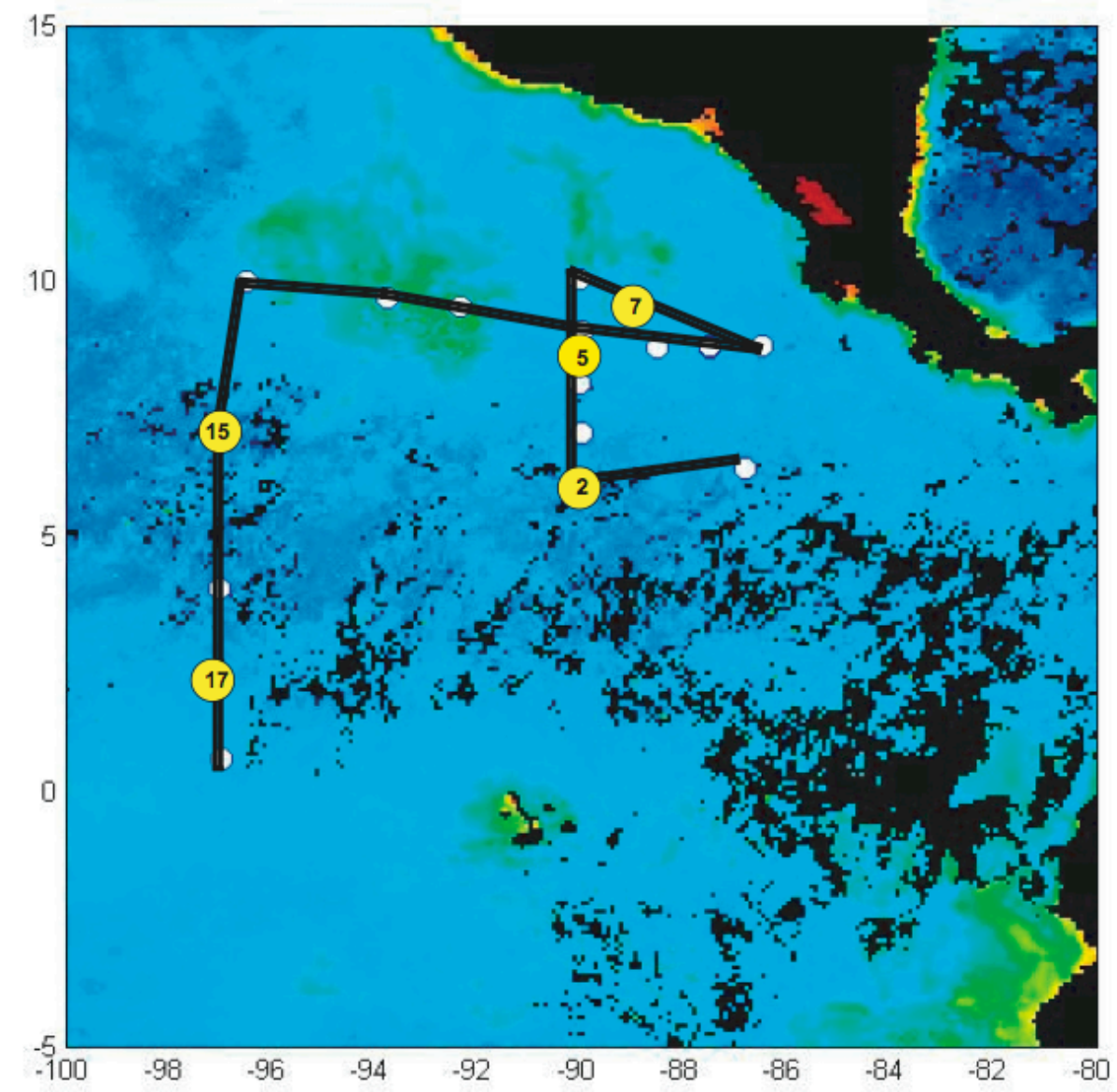

Figure 1: KN182-50 cruise track. Stations where culturing took place are labeled with yellow circles. Station 17 was located outside of the upwelling dome in a predicted high nutrient, low chlorophyll (HNLC) region. 
Culturing: Water samples were plated on $25 \mathrm{~mm}$ Petri dishes containing complex agar media from the five stations indicated on the cruise track (Fig. 1). Samples were taken at five depths, ranging from 8-200 $\mathrm{m}$ following the water column features. Samples were diluted $10^{-1}, 10^{-2}$, and $10^{-3}$ with sterile autoclaved seawater in addition to the undiluted sample. $20 \mu 1$ of each dilution was plated in triplicate onto the complex agar media and Chrome Azurol-S (CAS) agar media. Cultures were incubated at room temperature.

Batch media preparation: $1.0 \mathrm{~g}$ yeast extract (Difco), $1.0 \mathrm{~g}$ tryptone (Difco), $24.7 \mathrm{~g}$ $\mathrm{NaCl}, 0.7 \mathrm{~g} \mathrm{KCl}, 6.3 \mathrm{~g} \mathrm{MgSO}_{4} \cdot 7 \mathrm{H}_{2} \mathrm{O}, 4.6 \mathrm{~g} \mathrm{MgCl}_{2} \cdot 6 \mathrm{H}_{2} \mathrm{O}, 1.2 \mathrm{~g} \mathrm{CaCl}_{2} \cdot 2 \mathrm{H}_{2} \mathrm{O}, 0.2 \mathrm{~g}$ $\mathrm{NaHCO}_{3}, 15 \mathrm{~g}$ agar (Difco) per liter (Wagner-Dobler et. al 2003). Chemicals and agar

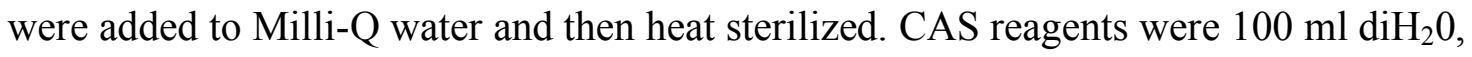
$60.5 \mathrm{mg}$ chrome azurol $\mathrm{S}, 1 \mathrm{ml}$ IronIII- $\mathrm{KCl}(10 \mathrm{x})$ solution (10X solution is $10 \mathrm{mM}$ $\mathrm{FeCl}_{3} \cdot 6 \mathrm{H}_{2} \mathrm{O}$ and $100 \mathrm{mM} \mathrm{KCl}$ ), and $72.9 \mathrm{mg}$ hexadecyltrimethylammonium bromide in 1L sterile seawater (Schwyn and Neilands 1987). Samples were incubated at room temperature for three days before storage at $4^{\circ} \mathrm{C}$. Culture plates were shipped back to the laboratory immediately after the cruise.

Six representatives of each colony morphology from cultured stations at each depth and dilution were picked and transferred to $150 \mu 1$ of liquid media in sterile 96-well plates (above recipe excluding agar and CAS reagents). 960 colonies were picked, of which 867 were ultimately isolated and survived. After three days of growth, cultures were streaked 
to isolation three times in sterile petri dishes containing the solid version of the same media. Isolated colonies were then picked and transferred to the liquid version of their initial isolation media (CAS was excluded from the recipe at this stage). Cultures were maintained in 96-well plate format, $150 \mu 1$ media/well. Every 1.5 weeks $3 \mu 1$ of each culture was transferred to fresh media using aseptic techniques. After initial chemical assays, the cultures were frozen in duplicate at $-80^{\circ} \mathrm{C}$ with $5 \%$ DMSO for preservation.

DNA Extractions: The cultures were diluted 1:10 culture:sterile water in fresh, sterile 96well plates (pre-DMSO preservation). The samples were run in an Eppendorf Mastercycler thermocycler for $10 \mathrm{mins}$ at $95^{\circ} \mathrm{C}$. The samples were then centrifuged for 5 min at $3000 \mathrm{x}$ g to pellet cellular debris. Plates were sealed and stored in a $-20^{\circ} \mathrm{C}$ freezer.

PCR: DNA was amplified using 8f and 1492r bacterial 16S rDNA primers: 8f: 5'AGAGTTTGATCCTGGCTCAG-3', and 1492r: 5'-GGTTACCTTGTTACGACTT-3'. $5 \mu 1$ of DNA template was used in a total reaction volume of $27.5 \mu 1$. Samples were amplified in 96 -well format. The amplification program was $95^{\circ} \mathrm{C}$ for $3 \mathrm{~min}$, followed by 25 cycles of: $95^{\circ} \mathrm{C} 1 \mathrm{~min}, 60^{\circ} \mathrm{C} 1 \mathrm{~min}, 72^{\circ} \mathrm{C} 1 \mathrm{~min}$, and final extension of $72^{\circ} \mathrm{C}$ for 10 min. $1 \%$ agarose gel electrophoresis was used to confirm presence and quality of extracted DNA.

Restriction fragment length polymorphism (RFLP) binning: In an effort to screen the 867 culture isolates obtained on the cruise, RFLP was performed as a preliminary 
diversity screen. Each PCR product was digested in a mixture containing $0.5 \mu 1$ of 20,000 $\mathrm{U} / \mathrm{ml}$ TaqI restriction endonuclease (New England Biolabs, Beverly, MA), $1 \mu 1$ of 10X TaqI buffer, $0.1 \mu 1$ of $100 \mathrm{ug} / \mathrm{ml}$ bovine serum albumin, $3.4 \mu 1$ of ddH2O, and $5 \mu 1$ of PCR product. The digests were incubated in an Eppendorf Mastercycler at $65^{\circ} \mathrm{C}$ for $1 \mathrm{hr}$. RFLP digest patterns were visualized with $2 \%$ agarose gel electrophoresis (Ehrenreich et al. 2005). A minimum of three representatives from each RFLP pattern obtained were chosen for further phylogenetic analysis.

PCR purification: Samples chosen for sequencing were then purified using the Quiagen PCR Purification kit according to the manufacturer's protocol.

Sequencing: Sequencing was carried out by Northwoods DNA, Inc. (Solway, MN). The 16S rDNA PCR product obtained were used for sequencing. Sequencing primers used were: 8f: 5'-AGAGTTTGATCCTGGCTCAG-3', 926r: 5'-ACCGCTTGTGCGGGCCC3', 519r: 5'-GWATTACCGCGGCKGCTG-3', 704r: 5'-GTAGCGGTGAAATGCGTAG A-3', and 1492r: 5'-GGTTACCTTGTTACGACTT-3'. High quality DNA sequences were obtained.

Phylogenetic Analysis: Sequence assimilation was conducted in Sequencher. Sequences were overlapped and only clean double-stranded sequences in excess of $1400 \mathrm{bp}$ were used in the alignment. Alignments and tree-building were completed in ARB using the GreenGenes database. The most up-to-date version of the GreenGenes database was used 
in tree building. All reference sequence alignments were double-checked for high quality and accurate alignments. X-Fig and PAUP were used for further tree modifications including creation of neighbor-joining trees and bootstrapping. Parsimony and distance bootstrapping/distance calculations all carried out at 1000x runs. Depth and siderophore data were added to trees in Adobe Illustrator CS.

Chrome Azurol-S (CAS) assay: All isolates were inoculated in triplicate in complex media with Dipyridyl added (200 $\mu \mathrm{M}$ final concentration) and iron-replete media. Original isolation media was used. Uninoculated dilution series of media with Desferral and Dipyridyl were used as positive and negative controls, respectively. All cultures were allowed to grow for $24 \mathrm{~h}$ at room temperature. At timepoint, samples were spun down for 5 minutes at $3000 \mathrm{x}$ g to pellet cells, and the supernatant was transferred to sterile 96-well plates. CAS reagent was added ( $15 \mu 1$ per $150 \mu 1$ media). Samples were allowed to react for $2 \mathrm{~h}$ before photographs of plates were taken and subsequent analysis of the assay began.

After binning via RFLP, the samples chosen for sequencing were analyzed again for CAS reactivity and siderophore structure type (using Arnow and Czacky assays below). Samples were CAS tested using the same procedure as above. 


\section{Siderophore category determination:}

The cultures that were chosen for sequencing were then grown up in triplicate $5 \mathrm{ml}$ volumes of iron replete and dipyridyl-spiked media using $50 \mu 1$ initial culture. Triplicate uninnoculated aliquots of iron replete and dipyridyl-spiked media were also incubated. After $24 \mathrm{~h}$ of growth at room temperature, samples were spun down and $1 \mathrm{ml}$ supernatant was transferred to a clean test tube, respectively, for each assay below.

\section{Arnow assay:}

This assay is the established and accepted assay use to test for the presence of catecholtype siderophores (among other chemical properties not relevant in this study).

One $\mathrm{ml}$ of each sample was placed in individual test-tubes graduate at $5 \mathrm{ml}$. One $\mathrm{ml}$ of the standard solution (50 mg 3,4-dihydroxyphenylalanine in $500 \mathrm{ml}$ distilled water, add 2 $\mathrm{ml} 0.1 \mathrm{~N}$ hydrochloric acid and bring to one liter volume with distilled water) was also placed in a graduated test tube. To each test tube the following was added in the given order, swirling after each addition: $1 \mathrm{ml} 0.5 \mathrm{~N}$ hydrochloric acid, $1 \mathrm{ml}$ nitrate-molybdate reagent (10 g sodium nitrate and $10 \mathrm{~g}$ sodium molybdate in $100 \mathrm{ml}$ distilled water), $1 \mathrm{ml}$ $1 \mathrm{~N}$ sodium hydroxide, and distilled water to bring the volume up to $5 \mathrm{ml}$ (Arnow 1937). 


\section{Czsaky assay:}

This assay is the established and accepted assay used to test for the presence of free hydoxamates, or hydroxyl-type siderophores.

To make standards, $1-5 \mathrm{ml}$ of $0.2-0.5 \mathrm{mg}$ hydroxylamine $\mathrm{N}$ is placed in a $10 \mathrm{ml}$ calibrated tube and $1 \mathrm{ml}$ of sulphanilic acid (10 g sulphanilic acid dissolved in $1000 \mathrm{ml}$ of $30 \%$ acetic acid by heating in a water bath) and $0.5 \mathrm{ml}$ iodine solution $(1.3 \mathrm{~g}$ iodine in $100 \mathrm{ml}$ glacial acetic acid) measured to it. After 3-5 minutes the excess of iodine is destroyed with $1 \mathrm{ml}$ of sodium arsenite solution ( $2 \mathrm{~g}$ sodium arsenite in $100 \mathrm{ml}$ distilled water) after adding $1 \mathrm{ml}$ alpha-naphthylamine solution (3 $\mathrm{g}$ alpha-naphthyline dissolved in $1000 \mathrm{ml}$ of $30 \%$ acetic acid.) the mixture is made up with distilled water to $10 \mathrm{ml}$. After 20-30 minutes, the color is developed.

A sample of $1 \mathrm{ml}$ of the solution to be tested and $1 \mathrm{ml}$ of $6 \mathrm{~N}$ sulfuric acid was placed in a Pyrex glass test tube with ground-in stopper carrying capillary tubing. The solution was boiled in a water bath for 6 hours and transferred to a $10 \mathrm{ml}$ tube. The excess of sulfuric acid was buffered with $3 \mathrm{ml}$ of $35 \%$ sodium acetate, and the free hydroxylamine was detected using the method above (Czsaky 1948).

Along with the samples, negative controls of uninnoculated iron replete and dipyridylspiked media were tested for the presence of hydroxamates. 


\section{Results:}

\section{Siderophore Production:}

All 867 isolates were tested for siderophore production. 340 out of the 867 (39.2\%) tested positive for siderophore production. 61 of the 340 have sequenced representatives in this study. Results organized by depth and station can be found below in Figures 2-6. Stations $2,5,7,15$ and 17 are represented.

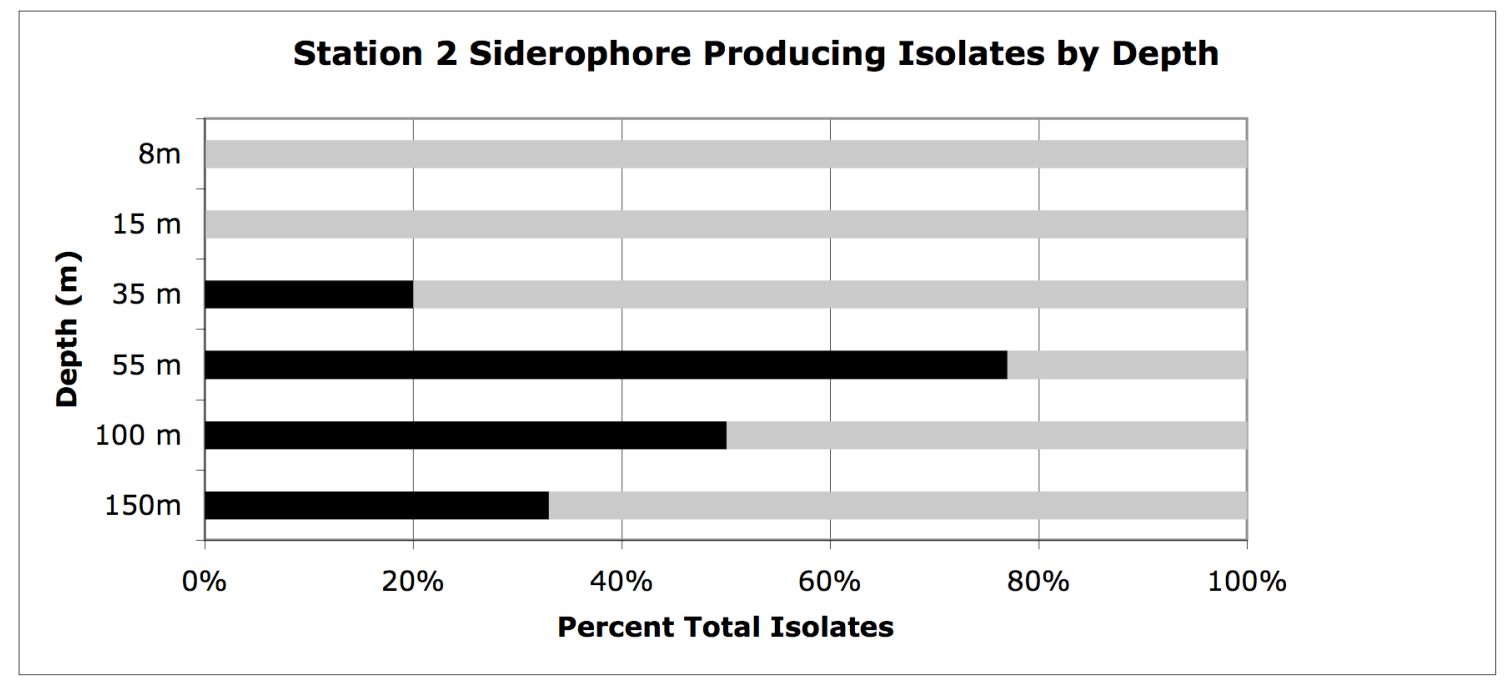

Figure 2: Station 2 siderophore producing isolates by depth. Black shows siderophore producers, gray shows non-producers. Shallow depth isolates failed to produce siderophores under experimental conditions. Siderophore producing isolates appeared at $35 \mathrm{~m}$ and peaked at a depth of $55 \mathrm{~m}$. 


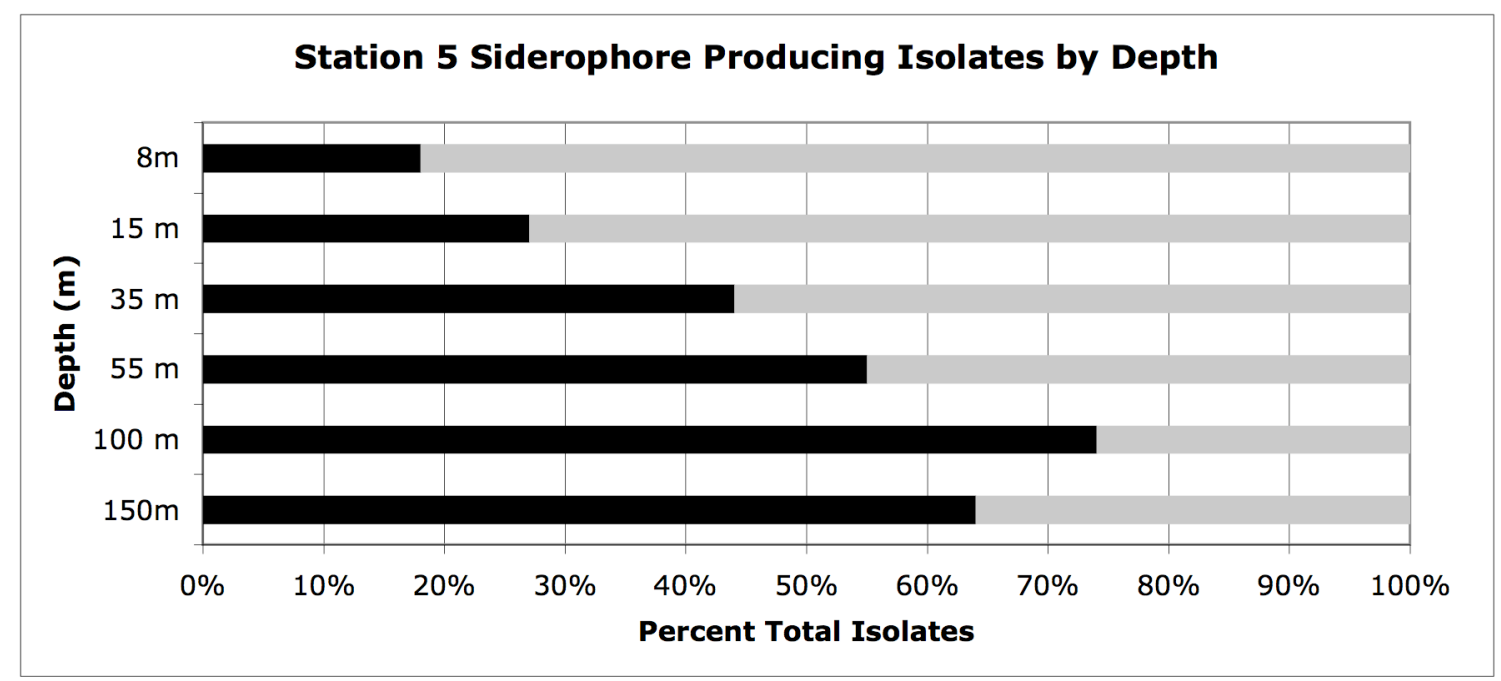

Figure 3: Station 5 siderophore producing isolates by depth. Black shows siderophore producers, gray shows non-producers. All depths showed isolate siderophore production under experimental conditions. Production peaked at a slightly deeper depth, $100 \mathrm{~m}$ at this station versus $55 \mathrm{~m}$ at Station 2.

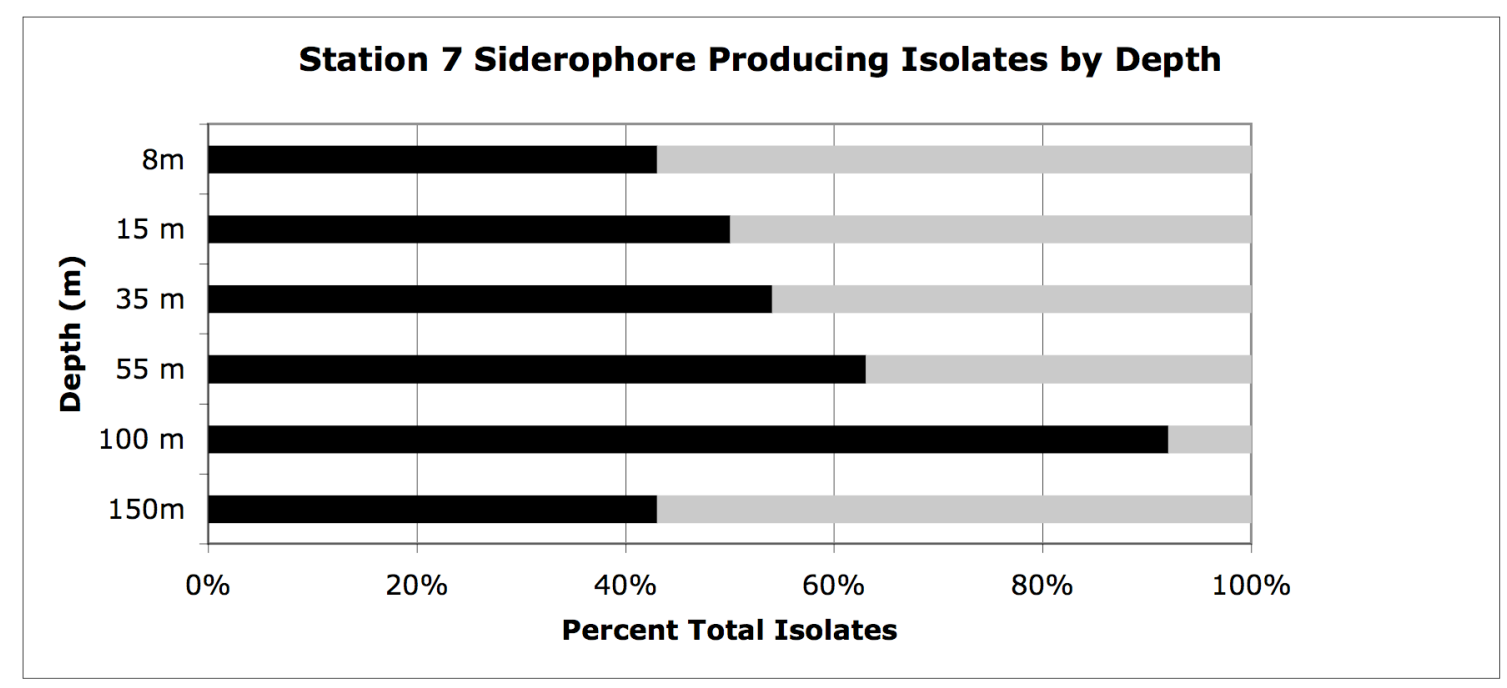


Figure 4: Station 7 siderophore producing isolates by depth. Black shows siderophore producers, gray shows non-producers. All depths showed relatively even numbers of siderophore producing isolates with the exception of a production peak at $100 \mathrm{~m}$.

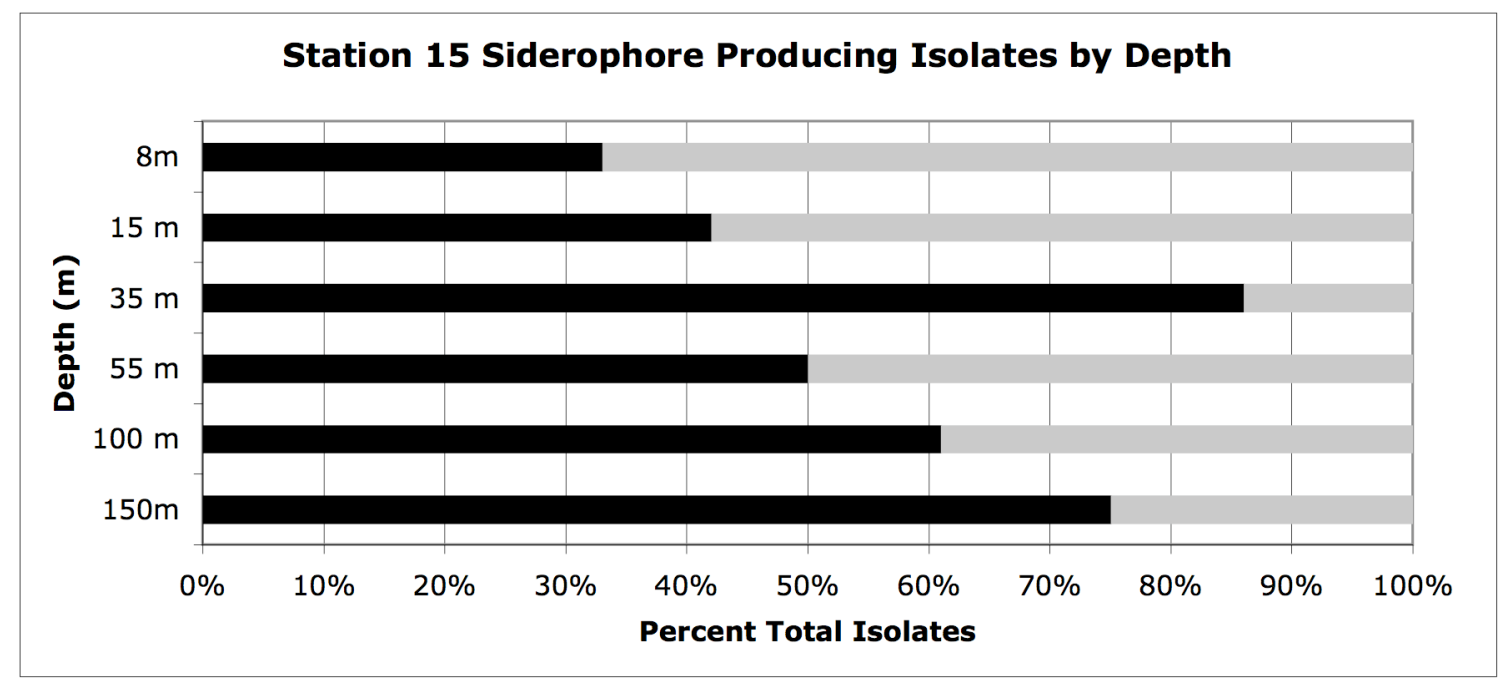

Figure 5: Station 15 siderophore producing isolates by depth. Black shows

siderophore producers, gray shows non-producers. Siderophore producing isolates have a major peak at the shallower depth of $35 \mathrm{~m}$ and another minor peak at $150 \mathrm{~m}$. All depths contained siderophore producing isolates. 


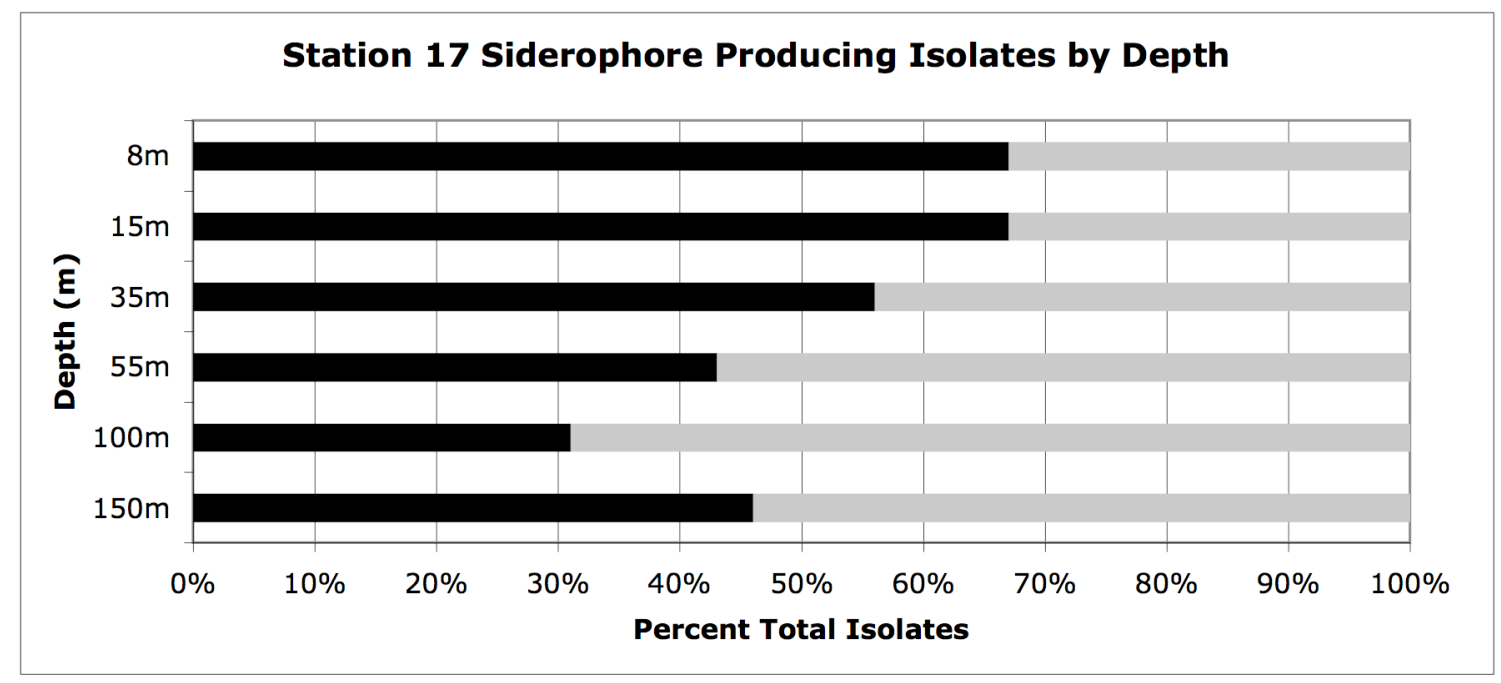

Figure 6: Station 17 siderophore producing isolates by depth. Black shows

siderophore producers, gray shows non-producers. This station showed the highest fraction of isolates having siderophore production capabilities in the shallow $8 \mathrm{~m}$ and $15 \mathrm{~m}$ waters.

Siderophore production capabilities appeared to increase with depth in stations 2-7. This trend appeared to reverse in stations 15 and 17, with production peaking at shallower depths. All stations showed siderophore production at all depths sampled with the exception of station 2, which did not show production capabilities at $8 \mathrm{~m}$ or $35 \mathrm{~m}$ under the experimental conditions. All stations contained at least one depth where a majority of isolates had siderophore producing capabilities. 


\section{Siderophore structural determination:}

Hydroxamate vs. catecholate structure was determined for all sequenced isolates. Results can be found in Figure 7 for overall siderophore type vs. depth, and Figures 15 and 16 for the same data for stations 2-15 and 17, respectively. Data for isolates from all stations shows approximately even hydroxamate vs catechol production in shallow waters with more isolates producing hydroxamates than catechols at $100 \mathrm{~m}$ and $150 \mathrm{~m}$. The siderophore structure type of three isolates was not determined due to unreactiveness with both the Czsaky and Arnow assays.

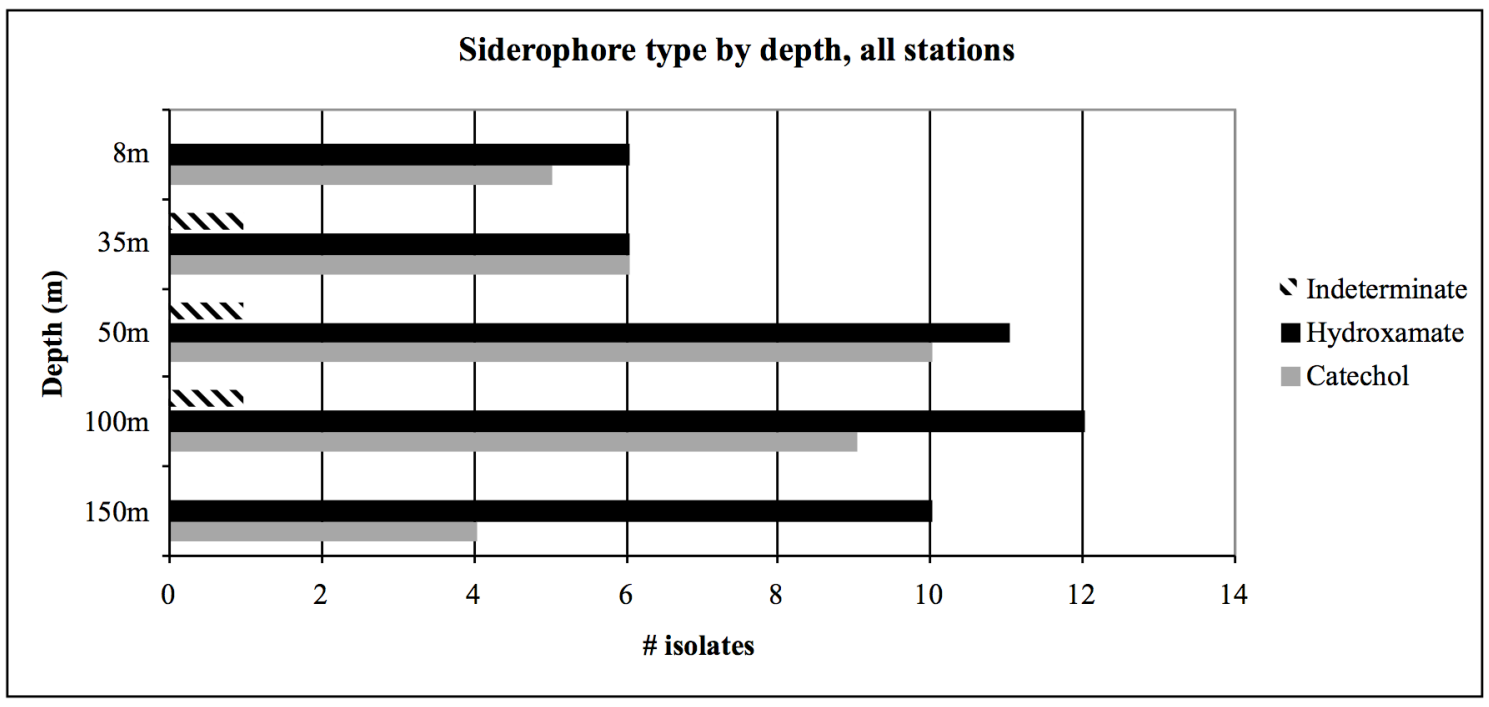

Figure 7: Siderophore type by depth, all stations.

When station 17 is omitted from the overall analysis, hydroxamate-type siderophores appear to dominate slightly more at depth (Figure 8). Station 17 has an equal number of 
hydroxamate and catechol producers at $8 \mathrm{~m}$ and $35 \mathrm{~m}$, but hydroxamates have a majority at $55 \mathrm{~m}$ and 100m (Figure 9). Only catechols were detected at $150 \mathrm{~m}$.

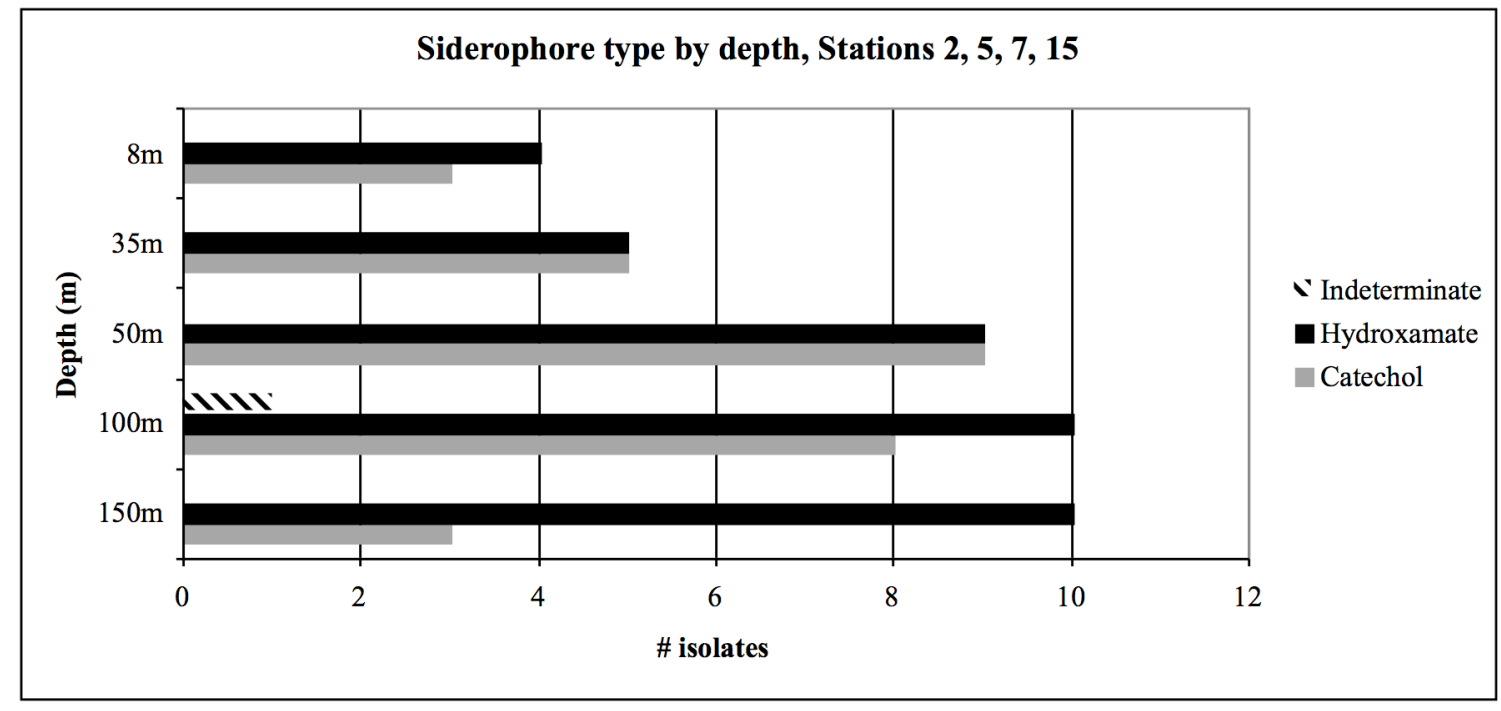

Figure 8: Siderophore type by depth, stations 2, 5, 7, 15.

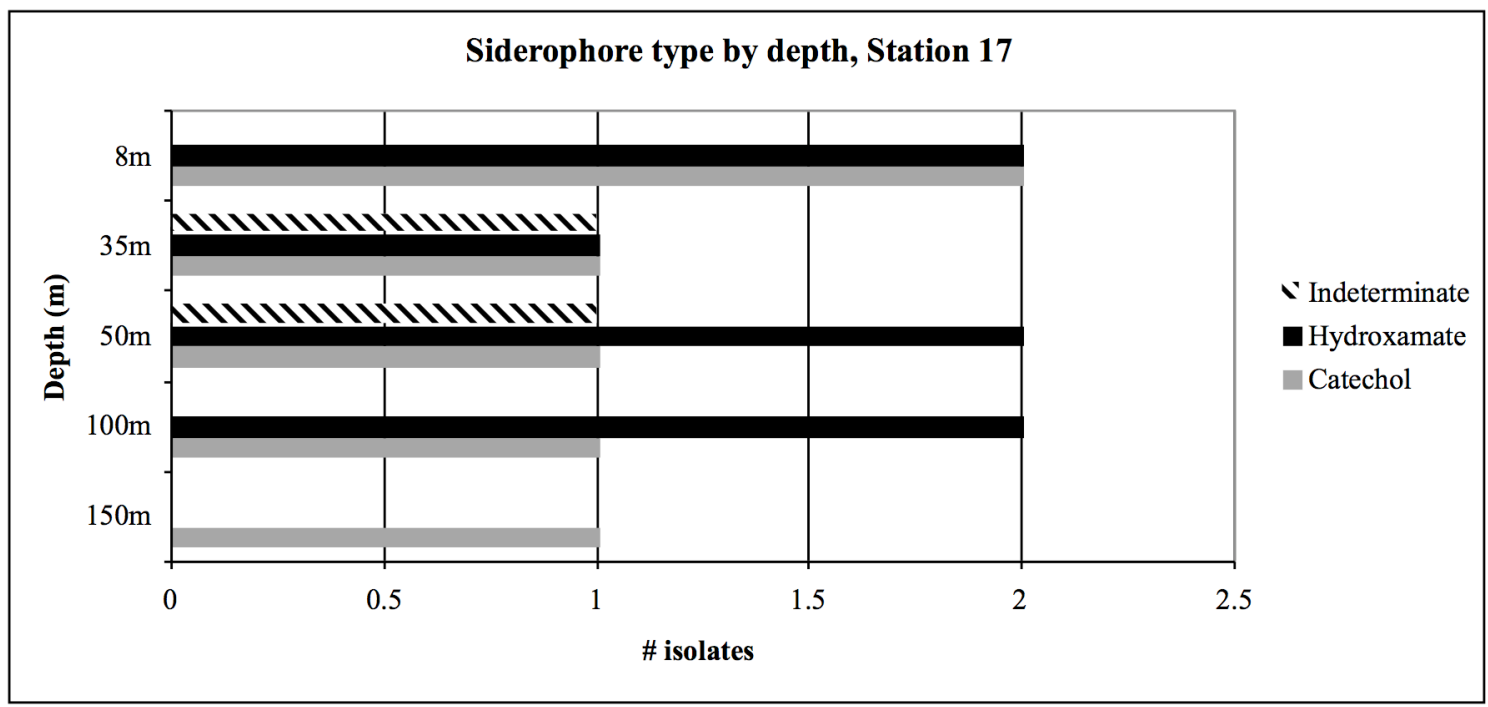

Figure 9: Siderophore type by depth, station 17. 
Alteromonas and Pseudoalteromonas were the most numerous groups within the isolates chosen for sequencing. Figures 10 and 11 show their siderophore production versus depth for all stations.

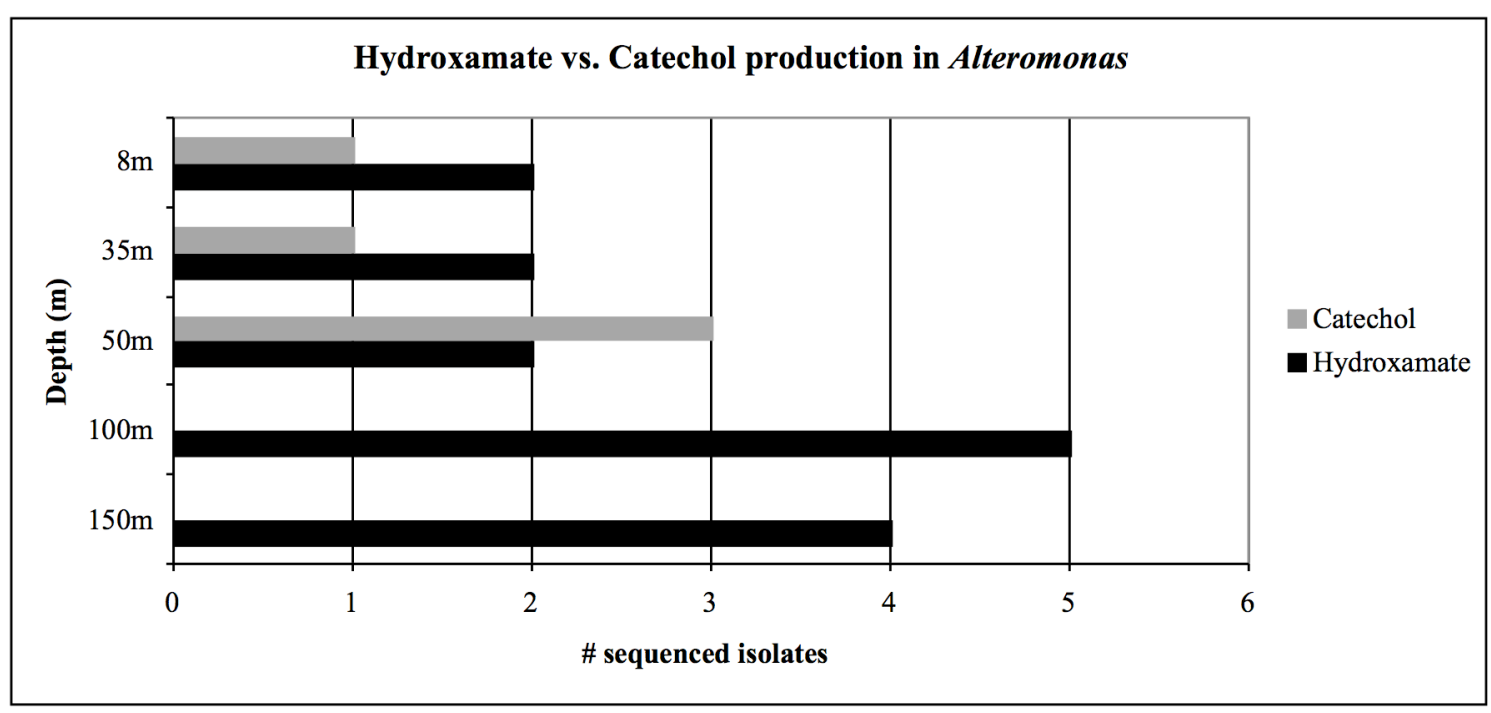

Figure 10: Alteromonas siderophore production vs. depth. Catechol production occurs in shallow isolates only. Hydroxamate production capabilities increase at depth. 


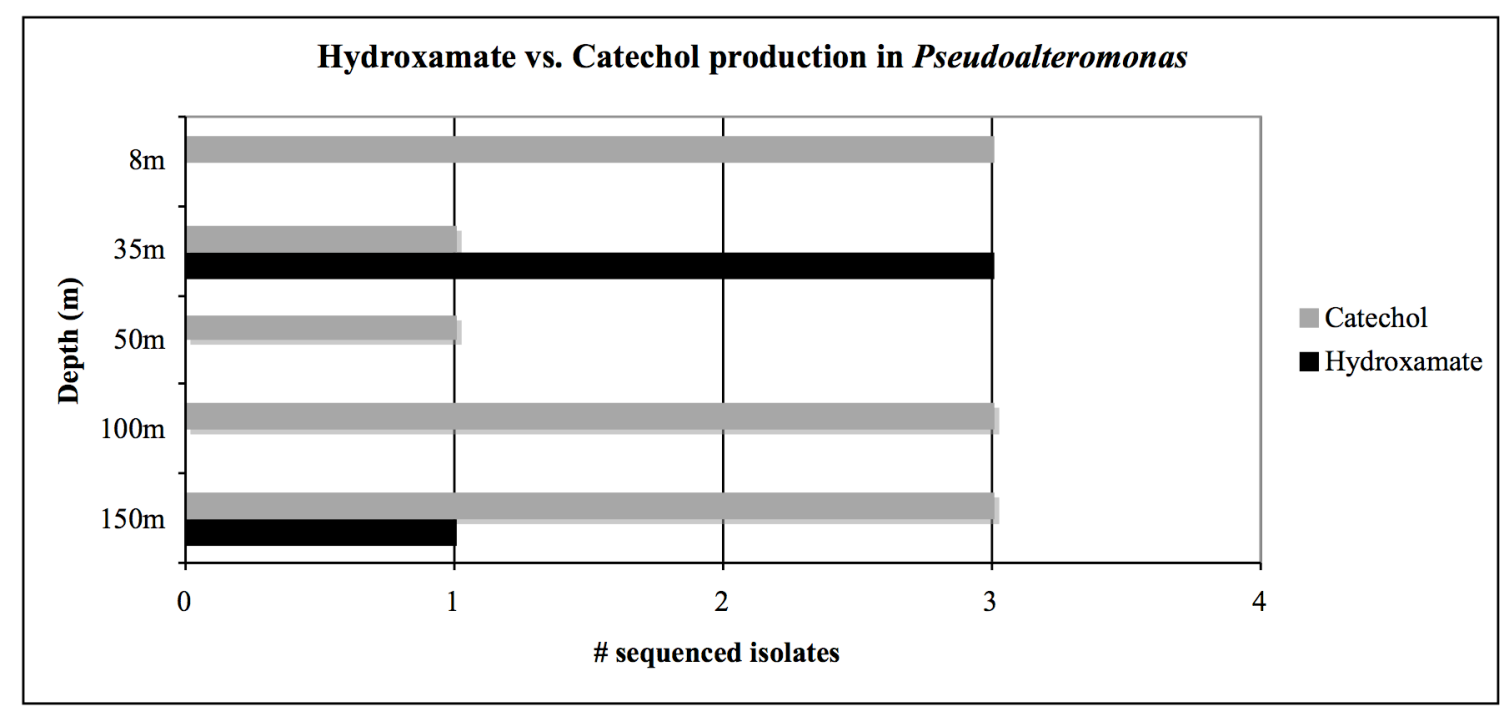

Figure 11: Pseudoalteromonas siderophore production vs. depth. Catechol production present at all depths. Hydroxamate production is only present at two depths. Catechol production is dominant overall for this subset of this taxonomic group.

\section{S rDNA Phylogeny:}

The sequenced isolates were predominantly gamma and alpha proteobacteria, with a few representatives from Flavobacteriales and Actinomycinae. Out of the 134 isolates from which high quality 16s rDNA sequences were obtained, 44 were Alteromonas, 37 were Pseudoalteromonas, 27 were Halomonas, 8 were Marinobacter, 6 were Idiomarina, 5 were Cytophaga, 3 were Roseobacter, 2 were Porphyrobacter, one was Alcanivoras, and one was an Aureo-Microbacterium. Figure 12 depicts the overall relationship of all sequenced isolates with each other in relation to the major bacterial, archaeal, and eukaryotic taxonomic groups. 


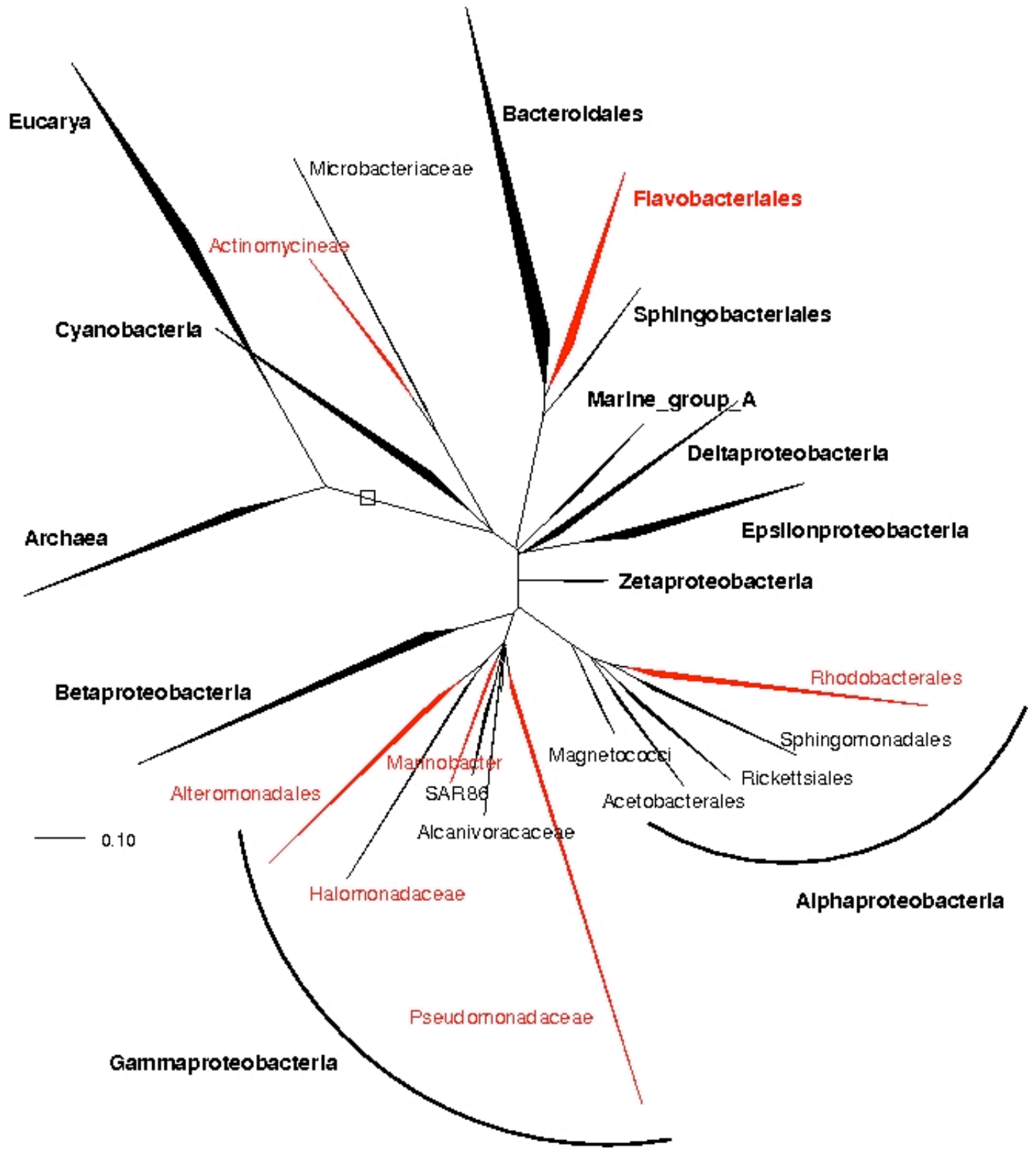

Figure 12: Overall relationship of cultured groups to other major taxonomic groups.

Isolates from this study are members of red groups. 
RFLP revealed 24 patterns within the original 867 isolates. Of these 24 patterns, $76.5 \%$ of isolates fell within 4 of the patterns $(32.1 \%, 25.9 \%, 11.1 \%$, and $7.2 \%$, see Figure 13$)$. All other patterns ranged from $0.2 \%-5.3 \%$.

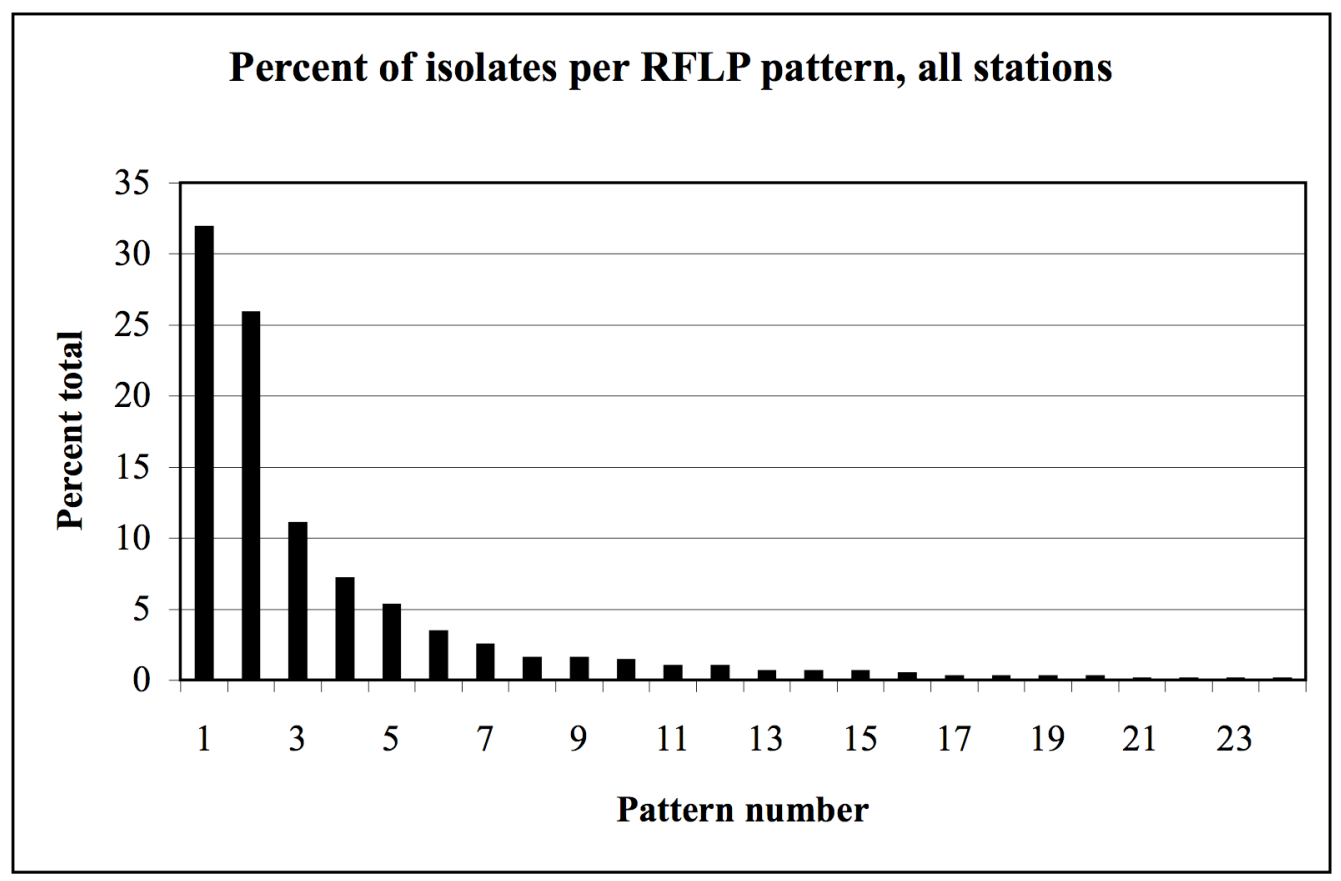

Figure 13: Percent of isolates per RFLP pattern obtained for all stations.

When broken down by phylogeny after $16 \mathrm{~S}$ rDNA sequencing, Alteromonas was made up of 9 patterns. Proportions among these 9 patterns very closely followed those of the overall group of isolates, with a slight increase in the largest group $(42.9 \%$ in Alteromonas versus $32.1 \%$ overall, see Figure 14). Pseudoalteromonas was more scattered, with 11 patterns represented and no group reaching over $23 \%$ of the total. Six of the 11 patterns ranged from $7.4 \%-22.2 \%$ (See Figure 15). Halomonas was composed of 11 distinct RFLP patterns with a fairly even distribution between 8 of the $12(12 \%$ - 
$20 \%$ of the total, Figure 16). Five patterns make up Marinobacter with isolates nearly evenly distributed between them (Figure 17). Three patterns make up the Idiomarina isolates but with so few isolates, it is difficult to draw conclusions from that data. Roseobacter and Cytophaga follow that trend with three and four patterns, respectively. 

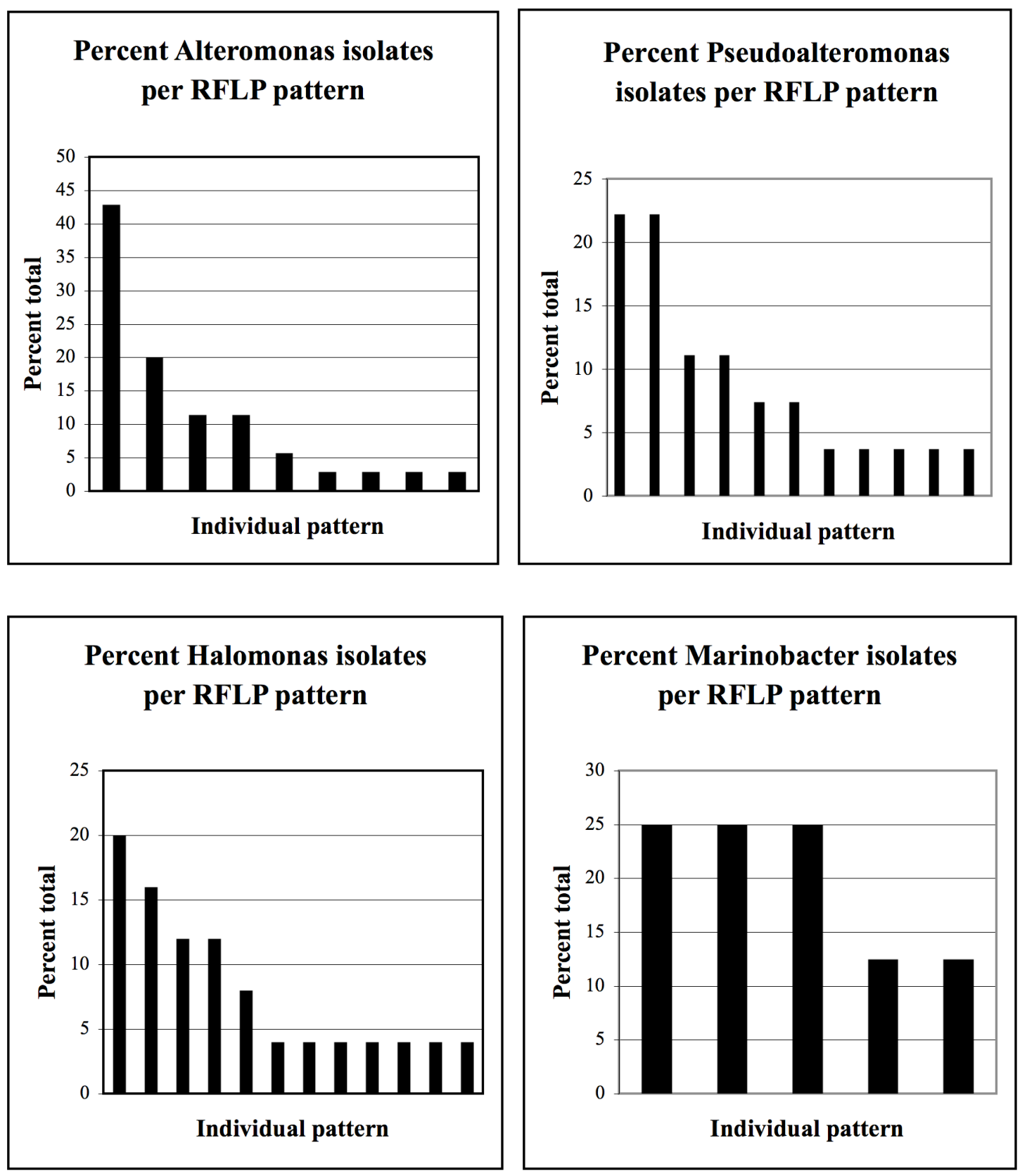

Figures 14-17: Percent total isolates for Alteromonas, Pseudoalteromonas, Halomonas, and Marinobacter distributed by RFLP pattern. 
When the siderophore production types are examined, catechol producers are spread among 13 patterns while hydroxamate producers are spread among 15 patterns. While both siderophore types basically follow the general pattern proportions of the overall isolate library, catechol producers have a slightly smaller representation of the largest pattern group (14.3\% versus $32 \%$ ) that is spread out amongst the other smaller groups. Both types of producers overlapped on all but three patterns, which each had exclusively from the other type of siderophore.

Figures 18-24 illustrate the phylogeny of the isolated sequences with siderophore production, station number, and depth information included. 
Figure 18: Phylogenetic tree of cultured Alteromonas isolates. Siderophore

production, type of siderophore produced, depth of isolation, and station are also

indicated. Siderophore production versus depth and station appeared to be fairly random.

No major patterns within the Alteromonas could be distinguished within this set of isolates. 


\section{Phylogeny and siderophore production of Alteromonas isolates}

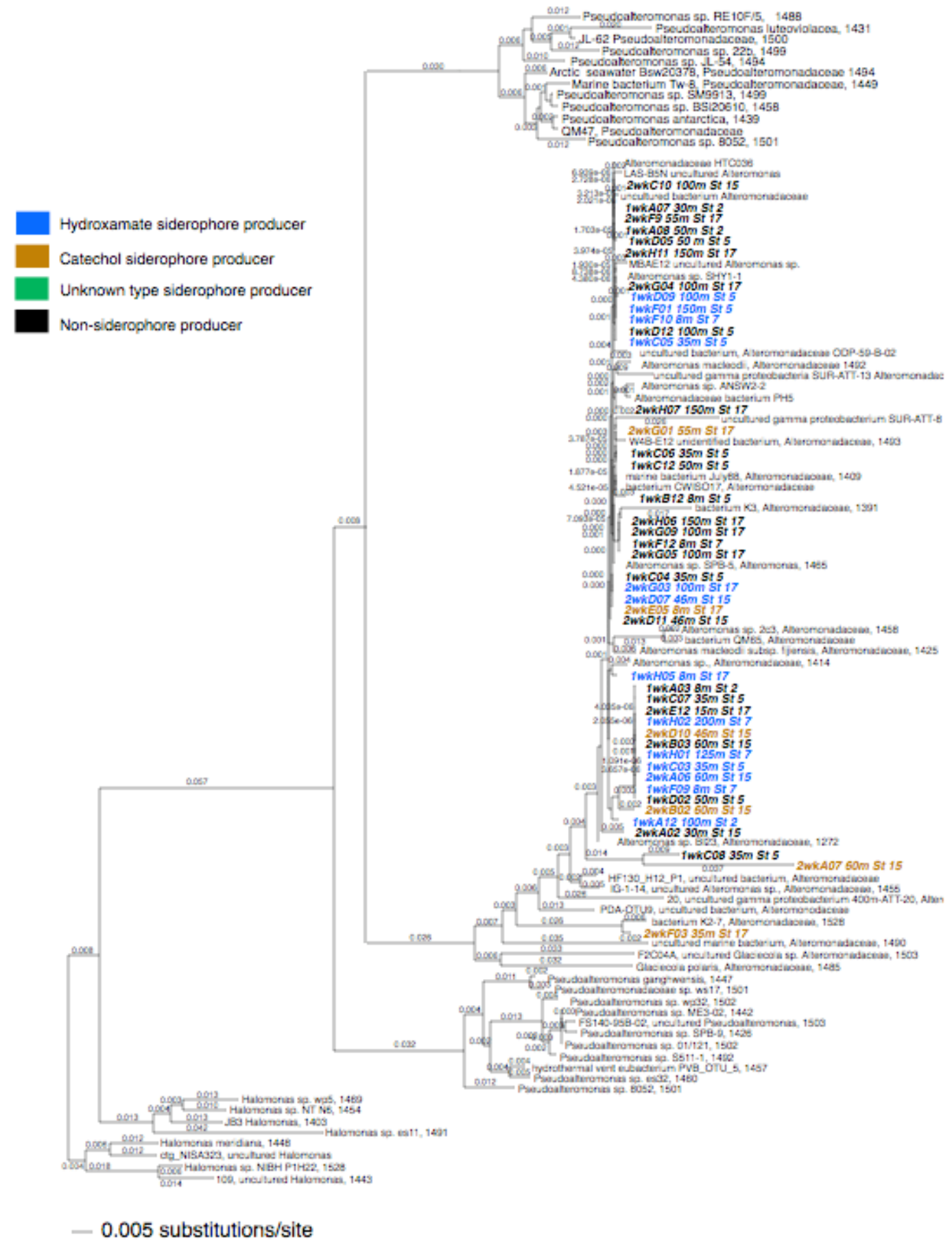


Figure 19: Phylogenetic tree of cultured Pseudoalteromonas isolates. Siderophore production capabilities, type of siderophore produced, depth of isolation, and station are also indicated. Isolates appear to be extremely closely related. Siderophore production versus depth and station appeared to be fairly random, with the exception of a small group of isolates from stations 15 and 17 that formed their own small group. No major patterns within the Pseudoalteromonas could be distinguished within this set of isolates. 


\section{Phylogeny and siderophore production of Pseudoalteromonas isolates}

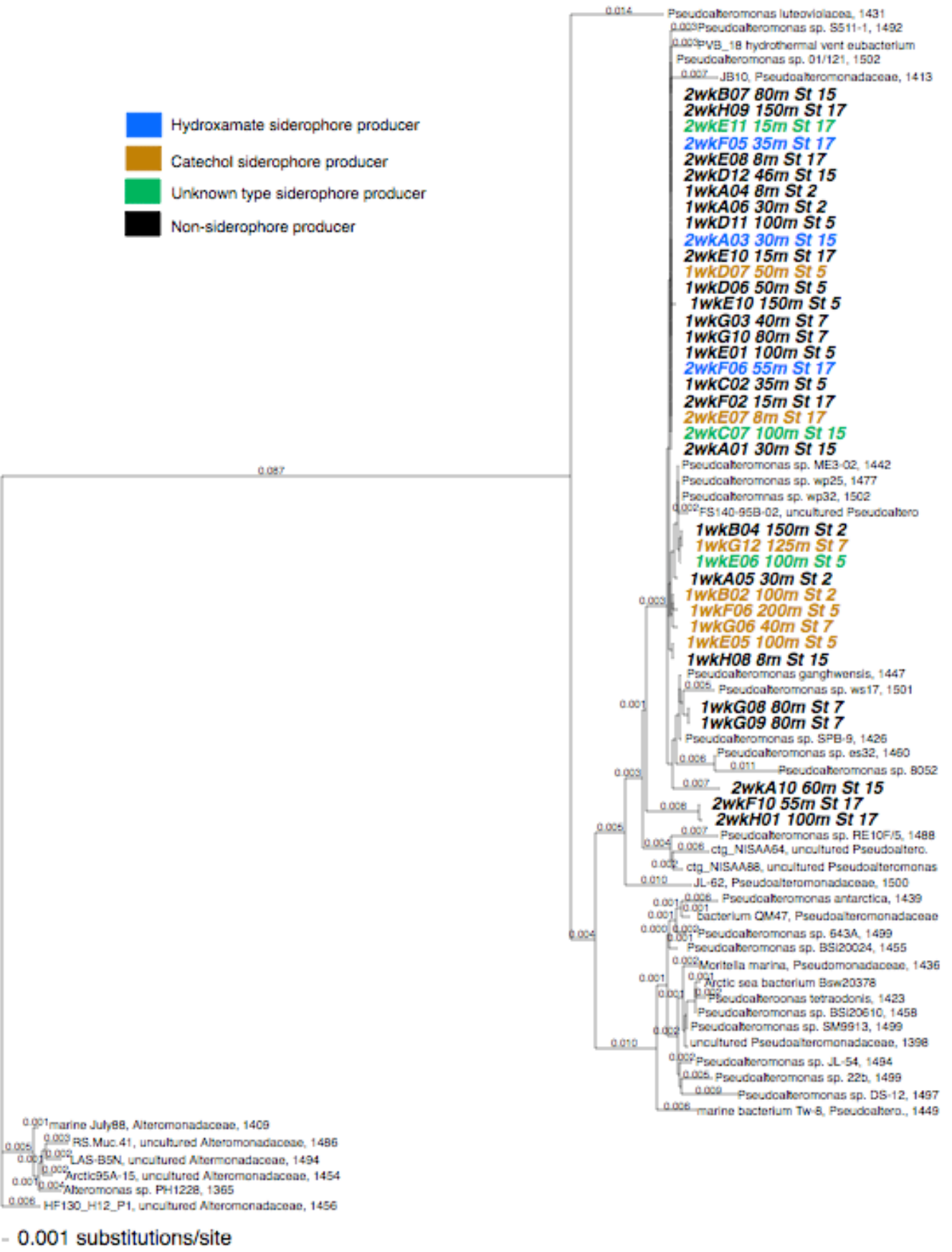


Figure 20: Phylogenetic tree of cultured Marinobacter isolates. Siderophore

production capabilities, type of siderophore produced, depth of isolation, and station are also indicated. Isolates appear to fall into two distinct phylogenetic groups, although they are not grouped according to depth, station, or siderophore production. 


\section{Phylogeny and siderophore production in Marinobacter isolates}

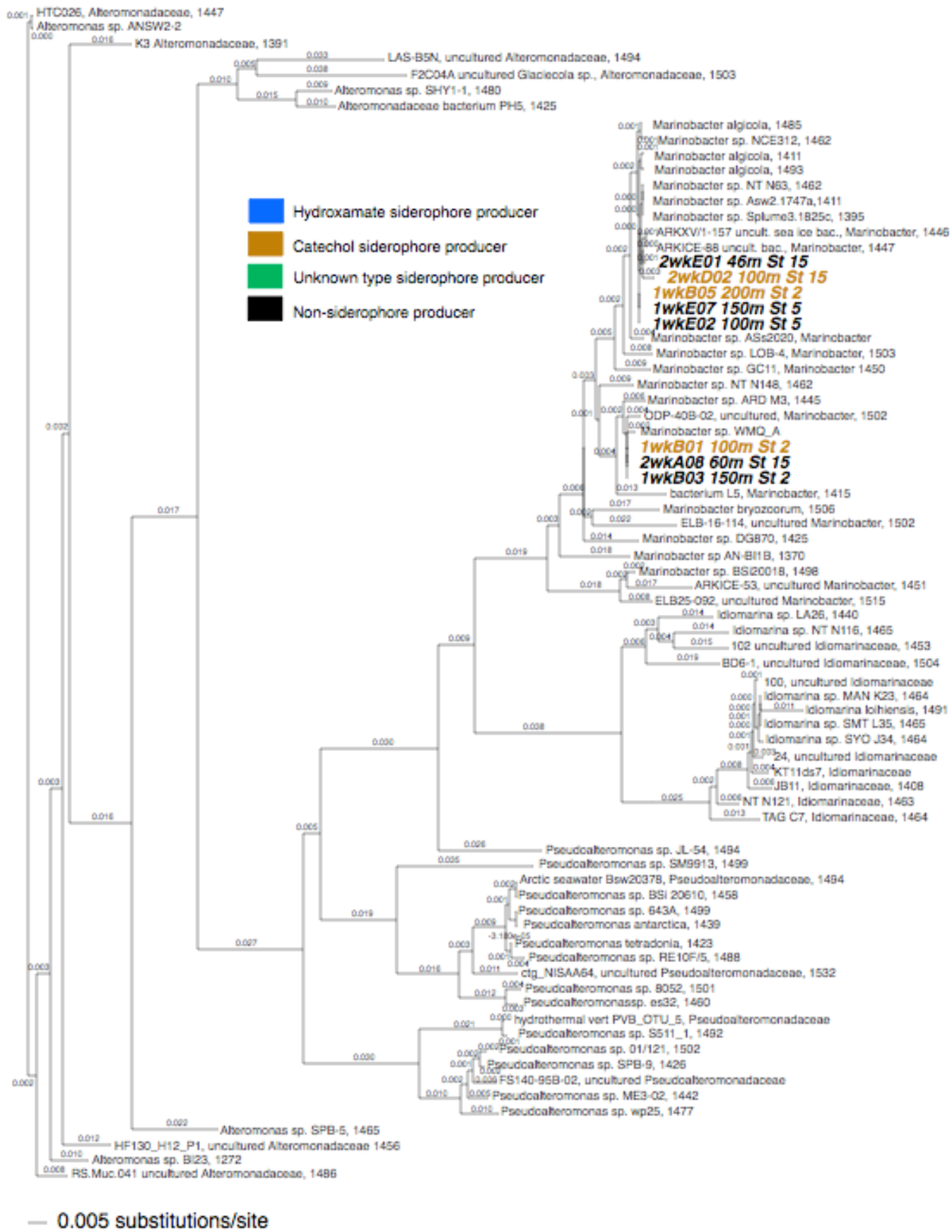


Figure 21: Phylogenetic tree of cultured Idiomarina isolates. Siderophore production capabilities, type of siderophore produced, depth of isolation, and station are also indicated. Within the highest-quality sequences used in building this tree, only stations 2 and 5 had Idiomarina isolates. 


\section{Phylogeny and siderophore production in Idiomarina isolates}

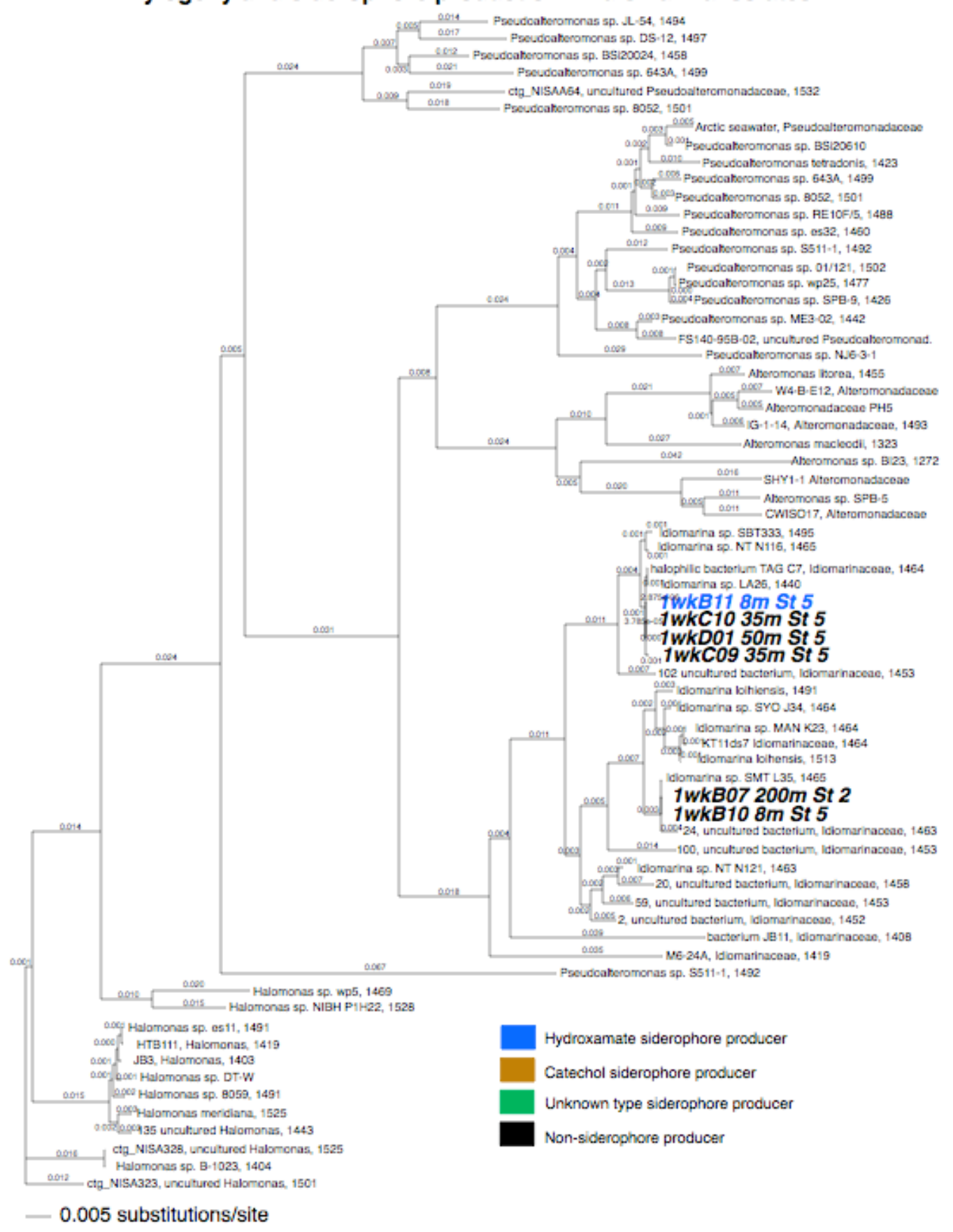


Figure 22: Phylogenetic tree of cultured Halomonas isolates. Siderophore production capabilities, type of siderophore produced, depth of isolation, and station are also indicated. Siderophore production and type do not coincide with phylogenetic affiliations. 


\section{Phylogeny and siderophore production in Halomonas isolates}

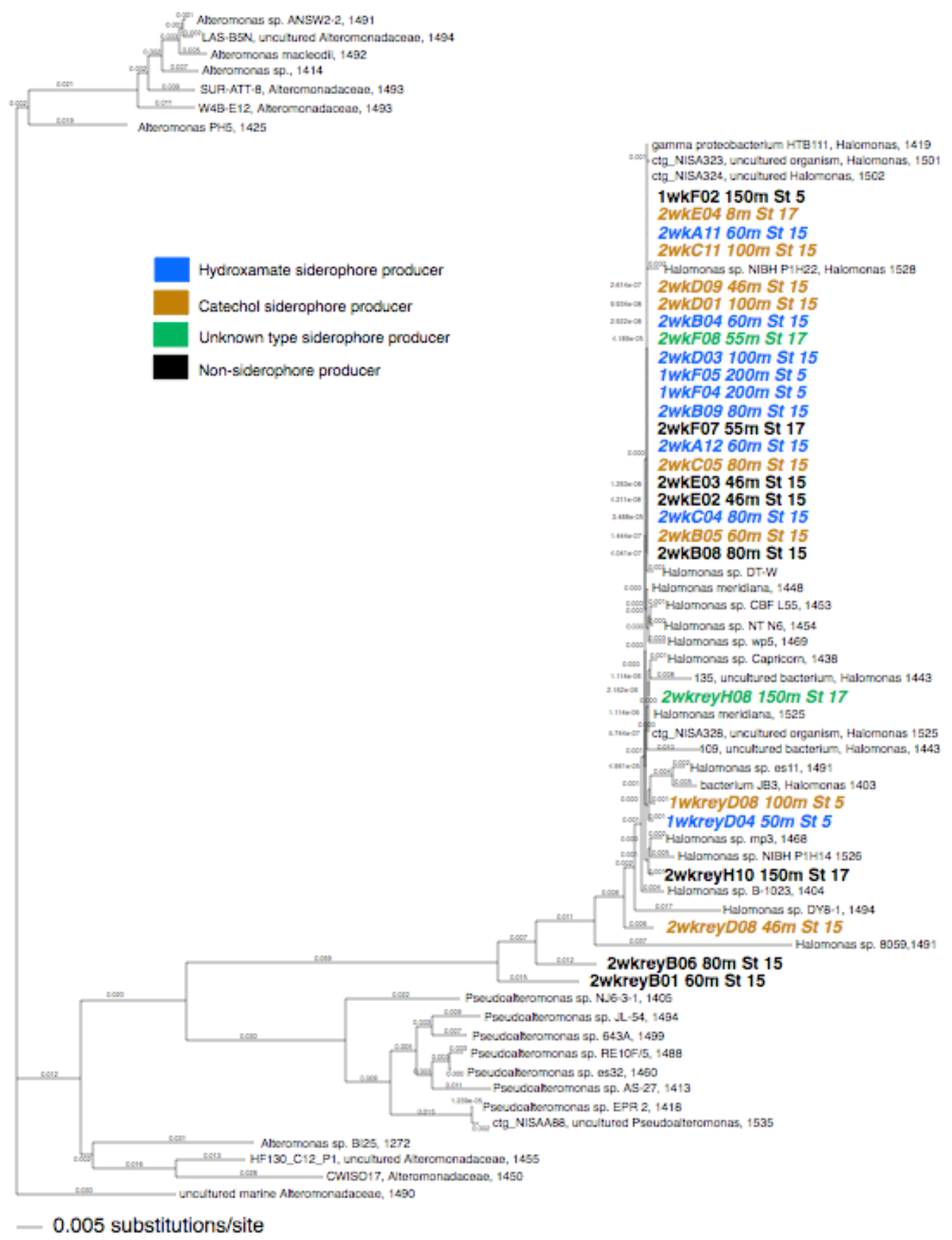


Figure 23: Phylogenetic tree of cultured Cytophaga isolates. Siderophore production capabilities, type of siderophore produced, depth of isolation, and station are also indicated. Three distinctive groups occur phylogenetically, although siderophore production and type of siderophore do not coincide with phylogenetic affiliation. 


\section{Phylogeny and siderophore production of Cytophaga isolates}

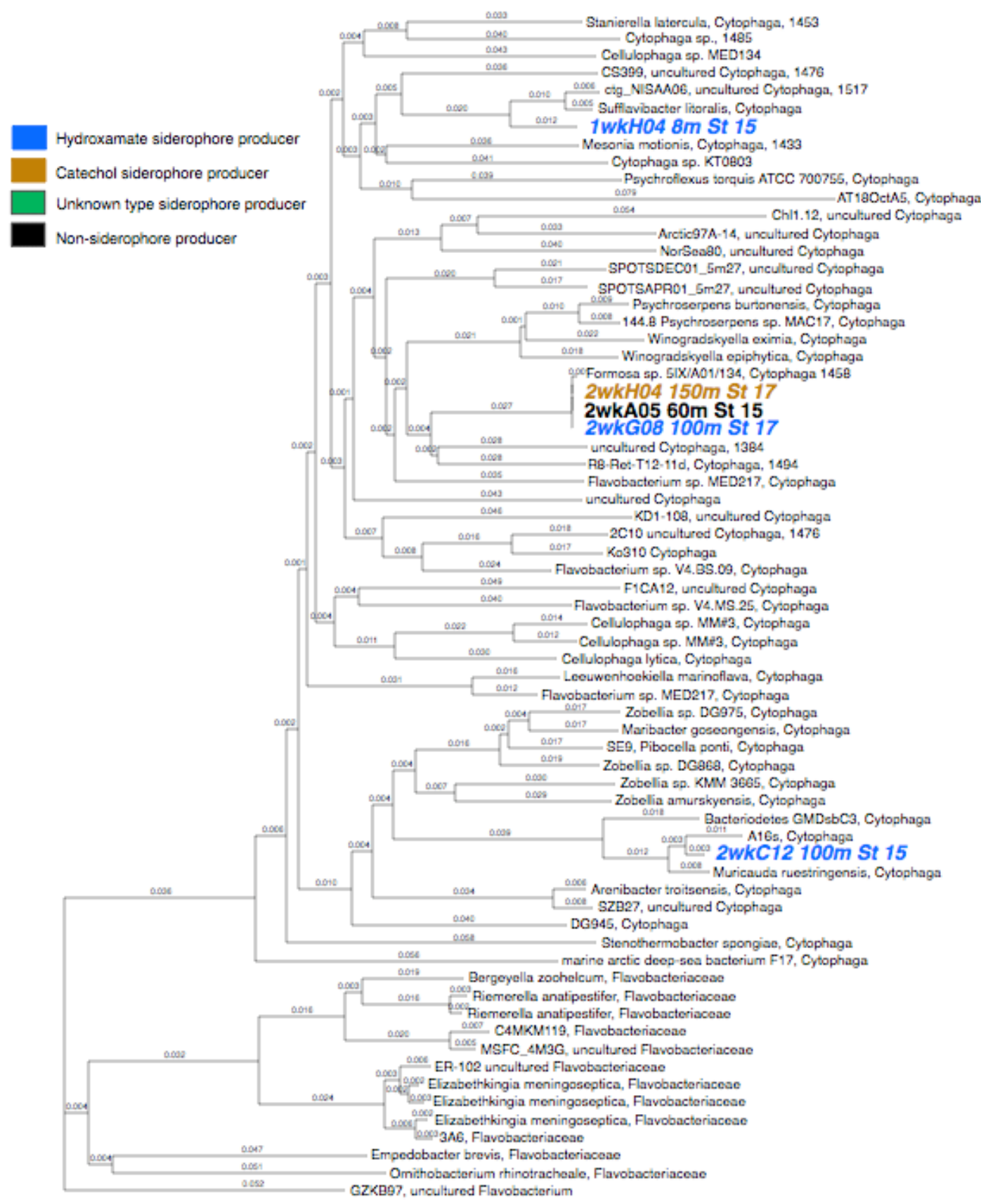

0.01 substitutions/site 
Figure 24: Phylogenetic tree of cultured Roseobacter and Porphyrobacter isolates.

Siderophore production capabilities, type of siderophore produced, depth of isolation, and station are also indicated. Isolates are not as closely related as in other groups such as Pseudoalteromonas and Alteromonas. This phylogenetic group only appeared below the chlorophyll maximum. 


\section{Phylogeny and siderophore production in Roseobacter and Porphyrobacter isolates}

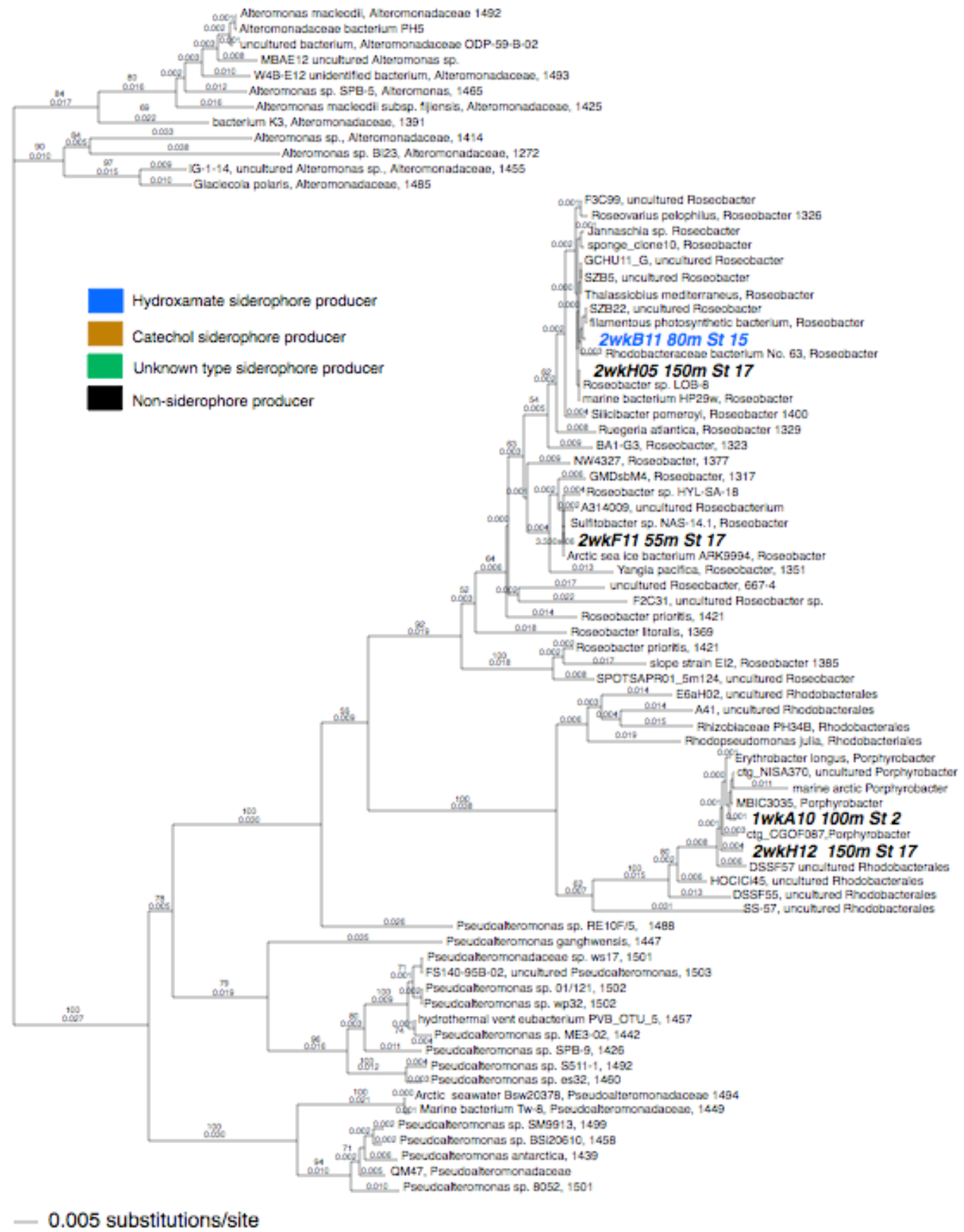




\section{Discussion:}

This library of isolates presented a unique opportunity for exploring the heterogeneity of iron scavenging systems within easily cultured bacterial populations in this region. Based on fluorescence measurements, Stations 5 and 7 appeared to be the most enveloped by the CRD. They also had the shallowest chlorophyll maxima at $35 \mathrm{~m}$ and $34 \mathrm{~m}$, respectively. Stations 2 and 15, while still in a highly productive area, are on the outskirts of the CRD. They had slightly deeper chlorophyll maxima at $51 \mathrm{~m}$ and $46 \mathrm{~m}$. Station 17 was well outside the CRD in a predicted HNLC region, and had the deepest chlorophyll maximum at $55 \mathrm{~m}$. The water column structure shifts between these stations suggests that the samples did in fact move through the upwelling and into nutrient depleted waters. These spatial and structural differences may well account for the shifts in the relative abundance of siderophore producing isolates between stations. Station 2, for example, has no siderophore production by isolates in shallow $8 \mathrm{~m}$ and $35 \mathrm{~m}$ waters. The depth of peak siderophore producing capabilities in the isolate library shifted deeper as the ship traveled through the $\mathrm{CRD}$, and shoaled again as the water became more nutrient-depleted.

While it is possible to use the CAS assay to quantify siderophores when used with pure isolations, quantification in environmental samples with unknown ligand composition has yet to be evaluated for reliability. The CAS assay indicates a compound's ability to remove iron loosely bound to the dye complex, and so can indicate the presence of both siderophore and other weaker iron-binding compounds. Uninoculated media, uninoculated media containing dipyridyl, and desferral were used as two negative and 
one positive control to rule out non-bacterial compounds as false positives. Czsaky and Arnow assays carried out on sequenced isolates suggest that there was siderophore production in the isolates, and that the CAS results were not simply other weaker ironbinding molecules. The fact that the results of the CAS assays were repeated with accuracy suggests that this is not an artifact of variable experimental conditions.

All stations contained at least one depth where the isolates were overwhelmingly siderophore-producers, suggesting a unique competitive structure exists at these depths. An increase in siderophore producing isolates could indicate that iron acquisition in that zone of the water column is more competitive, or that biologically-produced ligands are more successful in making iron bioavailable than in other zones in representatives from this library. Data on cobalt-binding and iron-binding ligands from this region suggests that there are trace-metal binding ligands in surface waters, which shows that while this library provides a window to microbial siderophore production in the ocean, it is not a complete picture (Saito et al. 2005, Rue unpublished).

Closely related isolates within the same group have different siderophore-producing capabilities, which suggests that there is a lot of genetic heterogeneity for this metabolic pathway. While the cellular biomass of the cultures tested for siderophore production was not normalized, all culture wells showed turbidity and $99.2 \%$ of reactions were decisive enough to be counted. The data shown in Figure 13 indicates that there are sequences from isolates within Alteromonas that are very closely related yet have differing 
siderophore producing capabilities. This trend is carried throughout the different phylogenetic groups represented by isolates in this study, suggesting genetic microheterogeneity.

Another interesting result is that under our experimental conditions, isolates of known siderophore producers did not always produce siderophores. Halomonas, Alteromonas, and Marinobacter isolates are representatives in this category. It is plausible - likely, even - that since our knowledge of these microbes' siderophore producing capabilities is based on a limited number of laboratory species and strains, that the range of their metabolic capabilities in the field is not fully characterized. Different strains may have different iron stress thresholds for siderophore gene expression. Furthermore, a negative result from a CAS assay does not rule out siderophore production - it may be that the siderophores are too dilute, are too weak to cause a color change, or react with iron in a way the assay cannot detect. The data certainly indicates that individual strains have the ability to compete for iron in different ways, even while using the same general strategy. This speaks to the complexity of biological impact on nutrient cycling in general - and the difficulty in teasing the microbial loop apart to find a clearer picture.

Just as with overall siderophore production patterns versus phylogeny, the type of siderophore produced seemed to be heterogeneous within taxonomic groups. When looking at the phylogenetic trees (Figures 13-19), Marinobacter (Figure 15) and Idiomarina (Figure 16) were the only taxonomic groups that did not include both 
catechol and hydroxamate-type siderophore producing strains under our experimental conditions. Within each group that contained both siderophore types, Pseudoalteromonas is the only one that seems to have a distinct grouping of catechol vs hydroxamate producers. This general lack of phylogenetic grouping suggests a high diversity of siderophore producing capabilities, and a lack of competitive advantage of one structure versus another. It also suggests a high rate of transfer of genes related to siderophore production within and between these groups, but more information is needed to confirm this.

High numbers of catechol producers in surface waters is unexpected due to the theory that catechol-type siderophores are more susceptible to photooxidation, and thus are predicted to be less prevalent in the photic zone than hydroxamate siderophores (Barbeau et al. 2003). The trend found in this study may be a result of the culturing bias of the isolate library obtained in this study. Because all siderophore producing microbes are not accounted for in this library, it is impossible to predict what trends would appear if the entire siderophore pool had been analyzed at each depth and station. Quantitative analysis to determine how large a fraction of the microbial population the isolates made up would provide insight into their influence on environmental siderophore production. Since uptake and utilization strategies have not been well characterized in marine bacteria, it is not yet possible to use these chemical properties for predicting how the photolabile nature of certain siderophores influences biological production. It is possible that the high turnover of these compounds could render their susceptibility to 
photodegredation unimportant from a biological standpoint. Studies on how structural changes affect siderophore receptor recognition would be the first step in understanding the link between chemical properties and biological function.

Because the Alteromonas and Pseudoalteromonas were the most highly represented groups, distinct hydroxamate and catechol production patterns were observed in the depth profile. Alteromonas was dominated by hydroxamate production, especially at depth. Catechol production only occurred in the shallowest three depths. Pseudoalteromonas was dominated by catechol production, with hydroxamates only being produced at $35 \mathrm{~m}$ and $150 \mathrm{~m}$. Although these groups are very closely related, they had different dominating siderophore structural classes. Again, the groups showed heterogeneity in their structural production. More sequenced representatives from the other groups would be an excellent way to compare their siderophore structural production patterns.

RFLP patterns of $16 \mathrm{~S}$ rRNA genes produced by this isolate library also show phylogenetic heterogeneity. While each group had different proportions of isolates within the different patterns, no group had less than three patterns represented. As Figures 13-17 show, the largest groups of isolates had members distributed widely across the patterns. This genetic diversity is also clear when the patterns of catechol versus hydroxamate producers are examined. Although each has three pattern groups exclusive to itself, they both have similar proportions among their shared pattern groups. A more detailed RFLP 
analysis at higher resolution could provide more information on subtle differences that occur among and between these groups.

By characterizing the siderophores produced by these isolates and determining the genetic make-up of the population, we can better understand the impact of siderophore production on iron cycling in this region. This appears to be the first large-scale genetic and siderophore production assessment of a heterotrophic population within both an upwelling and predicted high nutrient low chlorophyll regime (HNLC). One of the exciting aspects of marine microbiology is that many environmental processes are still, in a broader sense, not yet well characterized. Isolating specific components of a microbial community provides is a unique opportunity to manipulate, stress, and test their metabolic capabilities. The data derived from isolate collections such as this represents a step towards a better understanding of organisms and processes in the field. This sets the stage to study actual siderophore production - or other metabolic processes - in situ. By combining cultivation techniques with modern molecular methods, a more thorough understanding of bacterial processes in the environment, and their contribution to community interactions and biogeochemical processes is now becoming more possible.

The library of isolates described in this study should continue to provide opportunities to gain further insight into siderophore occurrence, distribution, and diversity. More complete structural analysis is possible with these laboratory models, which would add a substantial amount to current understanding of siderophore structure. These isolates may 
also facilitate gene knockout experiments, which could provide new gene markers to assess siderophore production, and possibly iron stress in the field. In summary, the work described in this study should facilitate new approaches to monitoring siderophore production in the field and better understand how they contribute to microbial survival, competition, and oceanic iron cycling. 


\section{Acknowledgements:}

I would like to thank Eric Webb for his leadership and support during this project. Adam Rivers, Dreux Chappell, Annette Hynes, and Nan Trowbridge were invaluable lab members. I would also like to thank Mak Saito, the chief scientist on the cruise for this project, as well as his laboratory for continued support. I thank John Waterbury for providing lab space as well as for being my advocate. I would like to thank Ed DeLong and Tracy Mincer for their help with the phylogenetic analysis in this project. I express thanks to the Captain and crew of the R/V Knorr for an exceptional cruise. I am grateful for the use of Dave Caron and Karen Casiotti's gel imaging system and gel box. I also thank the Academic Programs staff and my fellow Biology third years for their guidance and support.

I am grateful to my funding sources, National Science Foundation grants BO OCE0352241 "The Effect of Iron Bioavailability on Synechococcus diversity from a HNLC region to the Costa Rica upwelling dome" and CO-OCE-0452883 "Interactions of Cobalt and Iron with in situ Cyanobacterial Physiology in the South Atlantic and the Benguela Upwelling Region", the National Science Foundation Graduate Research Fellowship, and the Academic Programs office. 


\section{Works Cited:}

Andrews, S.C., Robinson, A.K. and F. Rodriquez-Quinones, 2003. Bacterial iron homeostasis. FEMS Microbiol Rev, 27: 215-237.

Armstrong, J.E., and C. Van Baalen, 1979. Iron transport in microalgae: the isolation and biological activity of a hydroxamate siderophore from the blue-green alga Agmenellum quadruplicatum. J. Gen. Microbiol. 111, 253-262.

Arnow, E., 1937. Colorimetric determination of the components of 3, 4Dihydroxyphenylalaninetyrosine mixtures. J. Biolog. Chem., 531-537.

Barbeau, K., E. L. Rue, C. G. Trick, K. W. Bruland, and A. Butler, 2003. Photochemical Reactivity of Siderophores Produced by Marine Heterotrophic Bacteria and Cyanobacteria Based on Characteristic Fe(III) Binding Groups. Limnol. Oceanogr. 48: 1069-1078.

Barber, R.T., and J.H. Ryther, 1969. Organic chelators: Factors affecting primary production in the Cromwell Current upwelling. J. Exp. Mar. Biol., 3: 191-199.

Beja, O., Spudich, E.N., Spudich, J.L., Leclerc, M., and E.F. DeLong, 2001. Proteorhodopsin phototrophy in the ocean. Nature, 411: 786-789.

Bickel, H., Hall, G.E., Keller-Schierlein, W., Prelog, V., Visher, E. and A. Wettstein, 1960. Stoffwechselprodukte von actinomyceten. Uber die konstitution von $\mathrm{f}$ errioxamin B. Helv. Chim. Acta, 43: 2129-2138.

Braun, V., Hantke, K. and W. Koster, 1998. Bacterial iron transport: Mechanisms, genetics, and regulation. In A. Siegel and H. Sigel (eds.), Iron transport and storage in microorganisms, plants and animals, v. 35. Marcel Dekker, pp. 67-145.

Braun, V. and H. Killman, 1999. Bacterial solutions to the iron-supply problem. Trends Biochem. Sci., 24:3389-3402.

Broenkow, W.H., 1965. The distribution of nutrients in the Costa Rica Dome in the Eastern Tropical Pacific Ocean. Limnol. Oceanogr., 10(1): 40-52.

Bruland, K.W., Orians, K.J., J.P. Cowen, 1994. Reactive trace metals in the stratified central North Pacific. Geochim. Cosmochim. Acta, 58: 3171-3182.

Buchanan, S.K. and others, 1999. Crystal structure of the outer membrane active transporter FepA from Esherichia coli. Nat. Struct. Biol., 6:56-63. 
Campbell, L., Nolla, H.A., and D. Vaulot, 1994. The importance of Prochlorococcus to community structure in the central North Pacific Ocean. Limnol. Oceanogr., 39: 954-961.

Coale, K.H., et al., 1996. A massive phytoplankton bloom induced by an ecosystem-scale iron fertilization experiment in the equatorial Pacific Ocean. Nature, 383: 495501.

Crichton, R.R., and R.J. Ward, 1992. Iton metabolism - new perspectives in view. Biochemistry, 31: 11255-11264.

Crichton, R.R., and R.J. Ward, 1998. Iron homeostasis. Met Ions Biol Syst, 35: 633-635.

Csaky, T.Z., 1948. On the estimation of bound hydroxylamine in biological materials. Acta Chem. Scand., 2: 450-454.

de Baar, H.J.W., Buma, A.G.J., Nolting, R.F., Cadee, G.C., Jaques, G. and P.J. Treguer, 1990. On iron limitation of the Southern Ocean: Experimental opservations in the Weddell and Scotia Seas. Mar. Ecol. Prog. Ser., 65: 105-122.

DuRand, M.D., Olson, R.J. and S.W. Chisholm, 2001. Phytoplankton population dynamics at the Bermuda Atlantic time series station in the Sargasso Sea. DeepSea Res. II, 48: 1983-2003.

Ehrenreich, I.M., Waterbury, J.B. and E.A. Webb, 2005. Distribution and diversity of natural product genes in marine and freshwater cyanobacterial cultures and genomes. Appl. Environ. Micro., 71(11): 7401-7413.

Ferguson, A.D., Hofmann, E., Coulton, J.W., Diederichs, K. and W. Welte, 1998. Siderophore-mediated iron transport: Crystal structure of FhuA with bound lipopolysaccharide. Science, 282: 2215-2220.

Fredrickson, J., Zachara, J., Balkwill, D. et al., 2004. Geomicrobiology of high-level nuclear waste-contaminated vadose sediments at the Hanford site, Washington state. Appl. Environ. Microbiol., 70 (7): 4230-41.

Gledhill, M. and C.M.G. van den Berg, 1994. Determination of complexation of iron(III) with natural organic complexing ligands in sea water using cathodic stripping voltammetry. Mar. Chem., 47: 41-54.

Goericke, R. and N. Welschmeyer, 1993. The marine prochlorophyte Prochlorococcus contributes significantly to phytoplankton biomass and primary production in the Sargasso Sea. Deep-sea Res. I, 40: 2283-2294. 
Gordon, R.M., Martin, J.H., G.A. Knauer, 1982. Iron in north-east Pacific waters. Nature, 299: 611-612.

Granger, J., and N. M. Price. 1999. The Importance of Siderophores in Iron Nutrition of Heterotrophic Marine Bacteria. Limnol. Oceanogr. 44:541-555.

Haygood, M.G., Holt, P.D., and A. Butler, 1993. Aerobactin production by a planktonic marine Vibria sp., Limnol. Oceanogr., 38(5): 1091-1097.

Hider, R.C., 1984. Siderophore mediated absorption of iron. Struct. Bond. Berlin, 58: 2687.

Hofmann, E.E., Busalacchi, A.J. and J.J. O'Brien. Wind Generation of the Costa Rica Dome. Science, 214: 552-554.

Hudson, R.J.M., 1998. Which aqueous species control the rates of trace metal uptake by aquatic biota? Observations and predictions of non-equilibrium effects. Sci. Total Environ., 219: 95-115.

Hutchins, D.A., Witter, A.E., Butler, and G.W. Luther III, 1999. Competition among marine phytoplankton for different chelated iron species. Nature 400, 858-861.

Kirchman, D.L., Meon, B., Cottrell, M.T., Hutchins, D.A., Weeks, D., K.W. Bruland, 2000. Carbon versus iron limitation of bacterial growth in the Californian upwelling regime. Limnol. Oceanogr., 45: 1681-1688.

Landing, W.M., and K.W. Bruland, 1987. The contrasting biogeochemistry of iron and manganese in the Pacific Ocean. Geochim. Cosmochim. Acta, 51: 29-43.

Lewis, B.L., P.D. Holt, S.W. Taylor, S.W. Wilhelm, C.G. Trick, A. Butler, and G.W. Luther III. Voltammetric etimation of Fe(III) thermodynamic stability constants for catecholate siderophores isolated from marine bacteria and cyanobacteria. Marine Chemistry 50 (1995), 179-188.

Lewis, B.L., Luther III, G.W., Lane, H. and T.M. Church, 1995. Determination of metalorganic complexation in natural waters by SWASV with pseudopolarograms. Electroalalysis, 7: 166-177.

Lewis, B.L., Holt, P.D., Taylor, S.W., Wilhelm, S.W., Trick, C.G., Butler, A. and G.W. Luther III, 1995. Voltammetric estimation of iron(III) thermodynamic stability constants for catecholate siderophores isolated from marine bacteria and cyanobacteria. Mar. Chem., 50: 179-188. 
Macrellis, H.M., Trick, C.G., Rue, E.L., Smith, G., and K.W. Bruland, 2001. Collection and detection of natural iron-binding ligands from seawater. Marine Chem., 76: 175-187.

Madigan, M. T., 2003. Anoxygenic phototrophic bacteria from extreme environments. Photosynthesis Research, 76: 157-171.

Maldonado, M.T., and N.M. Price, 1999. Utilization of iron bound to strong organic ligands by plankton communities in the subarctic Pacific Ocean. Deep-Sea Res. !, 46: $2447-2473$.

Martin, J.H. and S.E. Fitzwater, 1988. Iron deficiency limits phytoplankton growth in the north-east Pacific subarctic. Nature, 331: 341-343.

Martin, J.H., Gordon, R.M., Fitzwater, S., W.W. Broenkow, 1989. VERTEX: phytoplankton/iron studies in the Gulf of Alaska. Deep-Sea Res. 36, 649-680.

Martin, J.H., Gordon, R.M., S.E. Fitzwater, 1991. The case for iron. Limnol. Oceanogr., 36: 1793-1802.

Martin, J.H. et al., 1994. Testing the iron hypothesis in ecosystems of the equatorial Pacific Ocean. Nature, 371: 123-129.

Martinez, J.S., Zhang, G.P., Holt, P.D., Jung, H.-T., Carrano, C. J., Haygood, M. G. and A. Butler, 2000. Self-assembling amphiphilic siderophores from marine bacteria. Science, 287: 1245-1247.

Martinez, J. S., M. G. Haygood, and A. Butler. 2001. Identification of a natural desferrioxamine siderophore produced by a marine bacterium. Limnol. Oceanogr.

Martinez, J. S., J. N. Carter-Franklin, E. L. Mann, J. D. Martin, M. G. Haygood, and A. Butler. 2003. Structure and Membrane Affinity of a Suite of Amphiphilic Siderophores Produced by a Marine Bacterium. Proceedings of the National Academy of Sciences of the United States of America 100: 3754-3759.

Moore, J. K., Doney, S. C. and K. Lindsey, 2004. Upper ocean ecosystem dynamics and iron cycling in a global three-dimensional model. Global Biogeochem. Cycles, 18: GB4028.

Morel, F.M.M., N.M. Price, 2003. The biogeochemical cycles of trace metals in the oceans. Science, 300: 944-947.

Neilands, J.B., 1984. Methodology of siderophores. Struct. Bond. Berlin, 58: 1-24. 
Neilands, J.B., and K. Nakamura, 1991. Detection, determination, isolation, characterization and regulation of microbial iron chelates. In: WInkelman, G. (Ed.), CRC Handbook of Microbial Iron Chelates. CRC Press, Boca Raton, FL, pp. 1-14.

O'Brien, I.G. and F. Gibson, 1970. The structure of enterochelin and related 2,3dihydroxy-N-benzoylserine conjugates from Escherichia coli. Biochem. Biophys. Acta, 215: 393-402.

Pollack, J.R. and J.B. Neilands, 1970. Enterobactin, an iron transport compound from Salmonella typhimurium. Biochem. Biophys. Res. Commun., 38: 989-992.

Ratledge, C. and L.G. Dover, 2000. Annu. Rev. Microbiol., 54: 881-941.

Rue, E.L., and K.W. Bruland, 1995. Complexation of iron(III) by natural organic ligands in the Central North Pacific as determined by a new competitive ligand equilibration/adsorptive cathodic stripping voltammetric method. Mar. Chem., 50: 117-138.

Rue, E.L., and K.W. Bruland, 1997. The role of organic complexation on ambient iron chemistry in the equatorial Pacific Ocean and the response of a mesoscale iron addition experiment. Limnol. Oceanogr., 42: 901-910.

Ryther, J.H., and D.D. Kramer, 1961. Relative iron requirement of some coastal and offshore plankton algae. Ecology, 42: 444-446.

Saito, M.A., Rocap, G. and J.W. Moffett, 2005. Production of cobalt binding ligands in a Synechococcus feature at the Costa Rica upwelling dome. Limnol. Oceanogr., 50(1): 279-290.

Schwyn, B., and J.B. Neilands, 1987. "Universal CAS assay for the detection and determination of siderophores". Anal. Biochem., 160: 47-60.

Sugiuira Y. and K. Nomoto, 1984. Phytosiderophores: Structures and properties of mugineic acids and their metal complexes. Struct. Bond. Berlin, 58: 107-135.

Sunda, W.G. and S.A. Huntsman, 1995. Cobalt and zinc interreplacement in marine phytoplankton: Biological and geochemical implications. Limnol. Oceanogr., 40: 1404-1417.

Tortell, P.D., M.T. Maldonado, and N.M. Price. 1996. The role of heterotrophic bacteria in iron-limited ocean ecosystems. Nature 383: 330-332. 
van der Helm, D., 1998. The physical chemistry of bacterial outer-membrane siderophore receptor proteins. In A. Siegl and H. Sigel (eds.), Iron transport and storage in microorganisms, plants, and animals, pp. 355-401.

Wagner-Dobler, I, H Rheims, D A Felske, R Pukall and B J Tindall, 2003. "Jannaschia helgolandensis gen. nov., sp. nov., a novel abundant member of the marine Roseobacter clade from the North Sea”. Int. J. System. Evol. Micro., 53: 731-738.

Whitman, W., Coleman, D., and W. Wiebe, 1998. Prokaryotes: The unseen majority. Proc. Natl. Acad. Sci., 95 (12): 6578-6583.

Wilhelm, S.W., and C.G. Trick, 1994. Iron-limited growth of cyanobacteria: multiple siderophore production is a common response. Limnol. Oceanogr. 39, 1979-1984.

Wilhelm, S.W. and C.G. Trick, 1995. Physiological profiles of Synechococcus (Cyanophyceae) grown in iron-limited continuous culture. J. Phycol., 31(1): 7985.

Wilhelm, S.W., MacAuley, K., and C.G. Trick, 1998. Evidence for the importance of catechol-type siderophores in the iron-limited growth of a cyanobacterium. Limnol. Oceanogr., 43: 992-997.

Wu, J., and G.W. Luther, 1995. Complexation of Fe(III) by natural organic ligands in the northwest Atlantic Ocean by a competitive ligand equilibrium method and a kinetic approach, Mar. Chem., 50: 159-177. 